\title{
REVIEW
}

\section{Phenotypes and personalized medicine in the acute respiratory distress syndrome}

\author{
Michael A. Matthay ${ }^{1,2,3^{*}}$ (D, Yaseen M. Arabi ${ }^{4}$, Emily R. Siegel², Lorraine B. Ware ${ }^{5}$, Lieuwe D. J. Bos ${ }^{6}$, Pratik Sinha ${ }^{7}$, \\ Jeremy R. Beitler ${ }^{8}$, Katherine D. Wick ${ }^{2}$, Martha A. Q. Curley ${ }^{9}$, Jean-Michel Constantin ${ }^{10}$, Joseph E. Levitt ${ }^{11}$ \\ and Carolyn S. Calfee ${ }^{1,2,3}$
}

(c) 2020 Springer-Verlag GmbH Germany, part of Springer Nature

\begin{abstract}
Although the acute respiratory distress syndrome (ARDS) is well defined by the development of acute hypoxemia, bilateral infiltrates and non-cardiogenic pulmonary edema, ARDS is heterogeneous in terms of clinical risk factors, physiology of lung injury, microbiology, and biology, potentially explaining why pharmacologic therapies have been mostly unsuccessful in treating ARDS. Identifying phenotypes of ARDS and integrating this information into patient selection for clinical trials may increase the chance for efficacy with new treatments. In this review, we focus on classifying ARDS by the associated clinical disorders, physiological data, and radiographic imaging. We consider biologic phenotypes, including plasma protein biomarkers, gene expression, and common causative microbiologic pathogens. We will also discuss the issue of focusing clinical trials on the patient's phase of lung injury, including prevention, administration of therapy during early acute lung injury, and treatment of established ARDS. A more in depth understanding of the interplay of these variables in ARDS should provide more success in designing and conducting clinical trials and achieving the goal of personalized medicine.
\end{abstract}

Keywords: Acute respiratory distress syndrome, Acute lung injury, Sepsis, Pulmonary edema, COVID-19, Phenotype, Precision medicine

\section{Introduction}

The acute respiratory distress syndrome (ARDS) is defined clinically by the onset of acute respiratory failure with hypoxemia and bilateral pulmonary infiltrates on chest imaging that cannot be primarily attributed to volume overload, left ventricular dysfunction or chronic lung disease. However, these relatively simply clinical criteria do not capture the complexity and diversity of ARDS [1]. The syndromic definition of ARDS encompasses different clinical disorders associated with ARDS, a range of pulmonary physiologic abnormalities, varying

\footnotetext{
*Correspondence: Michael.matthay@ucsf.edu

${ }^{1}$ Department of Anesthesia, University of California San Francisco, San Francisco, CA, USA

Full author information is available at the end of the article
}

chest radiographic abnormalities, variability in biologic pathways of injury as reflected by plasma protein biomarkers and gene expression, diverse microbiologic etiologies, and an evolution over time ranging from early development of acute lung injury in spontaneously breathing patients to ventilated patients who meet the Berlin criteria of ARDS.

The theme of this article is to consider the potential for classifying ARDS into phenotypes on the basis of clinical, physiologic, radiologic, and biologic criteria that may lead to more targeted therapies that could improve clinical outcomes. For example, ARDS from pneumonia may be caused by a variety of pathogens. Identifying the causative microbiologic agent can lead to specific treatment that may be effective, as has been shown in the coronavirus disease 2019 (COVID-19) pandemic with the recent evidence that anti-viral therapy with remdesivir 
reduces morbidity [2]. As another example of how subdividing ARDS may be useful, patients with more moderate to severe hypoxemia $(\mathrm{P} / \mathrm{F}<150 \mathrm{mmHg})$ benefit from prone positioning [3]. One of the central challenges facing the field in ARDS is whether or how to incorporate our expanded knowledge of ARDS phenotypes into future clinical trials and practice, with the hope that this approach could identify subsets that will be more responsive to specific treatments beyond the current supportive care therapies that have improved clinical outcomes. We will also consider time dependent factors in the evolution of acute lung injury and ARDS, since this variable is one determinant of which therapies might be more effective.

The reader is also referred to a related article in this issue of Intensive Care Medicine that considers approaches to the design of ARDS trials based on prognostic and predictive enrichment strategies that identifies

\section{Take-home message:}

Integration of clinical, physiologic, radiographic, microbiologic and biologic variables can provide pathways for defining phenotypes and testing therapeutics in future clinical trials that can lead to a more personalized approach for therapies in ARDS.

some approaches that are based on physiologic, systemic, radiographic or biologic criteria [4].

\section{Clinical categories}

The development of ARDS is associated with a wide range of infectious and non-infectious clinical conditions (Fig. 1). Sepsis, primarily due to pneumonia, accounts for the majority of cases among both adults and children, though nonpulmonary sepsis (e.g., due to urinary tract infection, bowel perforation, or other causes) may

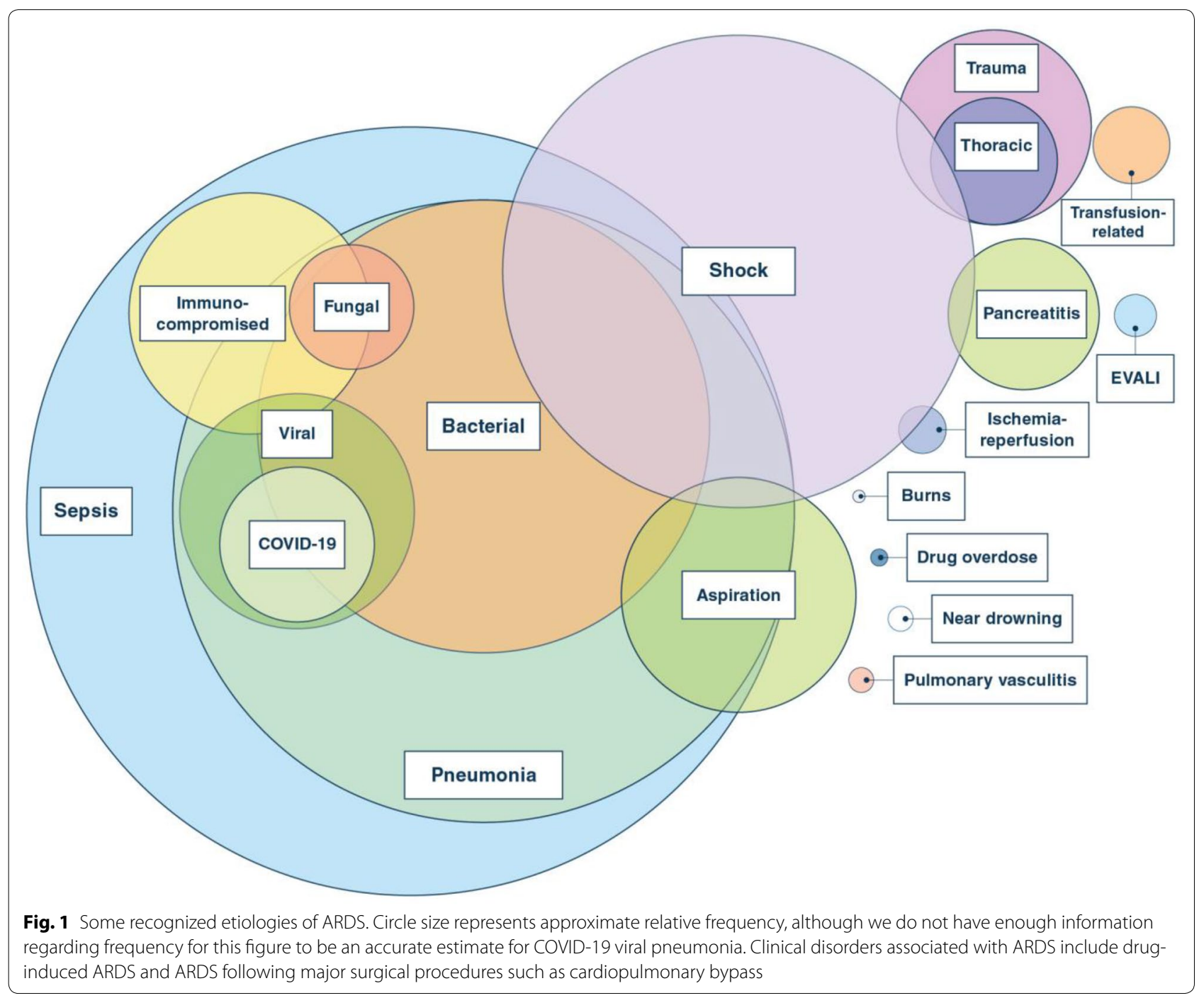


also lead to ARDS. Aspiration, trauma, and blood product transfusions are also common etiologies [5-8]. More recent clinical categories of ARDS include E-cigarette or vaping associated lung injury (EVALI) and the pandemic of SARS-CoV-2 related ARDS [9-11]. There are other clinical disorders associated with ARDS including smoke inhalation, acute exacerbations of interstitial lung disease and primary graft dysfunction following lung transplantation [12]. Negative pressure pulmonary and re-expansion pulmonary edema are often thought of as causes of ARDS, but they are primarily a form of hydrostatic pulmonary edema and not acute lung injury $[13,14]$.

Clinical categorization remains an important anchoring framework for both the management and prognosis of ARDS. For example, the presence of sepsis not only guides antimicrobial strategy, but also is associated with more severe illness and worse outcomes [15] and has informed clinical trial design by enrolling patients with a common risk factor [16, 17]. Whether or not shock is present offers further specificity to clinical classification, although the presence or absence of shock does not readily distinguish patients identified by biologic factors [18, 19]. Clinical categories of ARDS classified as direct (e.g., pneumonia, aspiration, or ischemia-reperfusion injury) or indirect (e.g., non-pulmonary sepsis, multiple transfusions, pancreatitis) differ in clinical predictors of mortality and in their biomarker profiles; however, there is as yet no evidence that treatment responses consistently differ on this basis [20, 21].

Mortality from ARDS overall has decreased since the syndrome was first described [22, 23]; however, mortality continues to differ by clinical risk factor. In 2001, one study noted that the mortality of patients in a clinical trial of low tidal volume ventilation ranged from $43 \%$ in patients with sepsis to $11 \%$ in those who had sustained major trauma [24]. Data from 2006-2014 showed a similar mortality rate for sepsis starting at $46 \%$ and declining to $40 \%$ [25]. Of note, the mortality rate for trauma started at above $20 \%$ with an upward trend over the study interval. This lack of improvement in mortality in the trauma group was confirmed in a recent study comparing data from 1990 through 2009 [26]. Mortality in this study was also above $20 \%$, though much of this may be attributable to traumatic brain injury [27]. The incidence of transfusion associated lung injury (TRALI) has significantly decreased with the discovery that fresh frozen plasma from female patients was a major factor in TRALI pathogenesis $[28,29]$. Recent studies suggest that the risk of developing ARDS is greater with direct than indirect injury [30], and although predictors of mortality differ between direct and indirect ARDS, overall mortality rates are likely similar [20,30]. In addition, one recent study from two institutions reported that attributable mortality in patients who developed ARDS from sepsis was primarily related to the initial severity of hypoxemia $\left(\mathrm{PaO}_{2} /\right.$ $\mathrm{FiO}_{2}<100 \mathrm{mmHg}$ ) [31].

The different clinical categories associated with ARDS illustrate the complexity of ARDS in terms of pathogenesis and also highlight how personalized medicine approaches will need to consider how the associated clinical category influences therapy. For example, patients with COVID-19 ARDS probably benefit from the antiviral therapy, remdesivir, but additional data are needed to confirm whether mechanically ventilated patients truly benefit [2]. Survival in these patients is improved by the use of the anti-inflammatory therapy dexamethasone [32], in contrast to the uncertain benefit of corticosteroids in unselected cohorts of patients with ARDS who do not share a common clinical risk factor [33, 34]. This discrepancy illustrates the potential value of focusing on distinct ARDS phenotypes based on clinical risk factor-that is, the signal for corticosteroid benefit is much clearer in COVID-19 ARDS than it has been in 50 years of study in non-COVID-19 ARDS. However, even the role of corticosteroids in COVID-19 will require more study to understand when dexamethasone may be harmful or beneficial [35] and will need re-evaluation in conjunction with new therapies that may show efficacy as well, including potentially monoclonal antibodies, immunomodulatory agents, and new anti-viral therapies.

\section{Physiologic categories}

In adult ARDS, the Berlin definition categorizes mild ARDS as a $\mathrm{PaO}_{2} / \mathrm{FiO}_{2}$ of $201-300 \mathrm{mmHg}$, moderate as $\mathrm{PaO}_{2} / \mathrm{FiO}_{2}$ of 101-200 mmHg, and severe as $\mathrm{PaO}_{2} / \mathrm{FiO}_{2}$ of equal to or less than $100 \mathrm{mmHg}$ (Table 1) [36]. Criteria for moderate and severe ARDS also require invasive mechanical ventilation with positive end-expiratory pressure (PEEP) of $5 \mathrm{cmH}_{2} \mathrm{O}$ or greater, while in mild ARDS, the PEEP requirement can be met noninvasively. In a patient-level meta-analysis, mortality increased from $27 \%$ to $32 \%$ to $45 \%$ for mild to moderate to severe ARDS [36, 37]. Several recent trials have used $\mathrm{PaO}_{2} / \mathrm{FiO}_{2}$ for prognostic enrichment, with $\mathrm{PaO}_{2} / \mathrm{FiO}_{2}$ eligibility thresholds of no more than 150 or 200 being most common [3, 38-40]. $\mathrm{PaO}_{2} / \mathrm{FiO}_{2}$ has important limitations, however, including being heavily influenced by ventilator settings, especially PEEP [41, 42].

Higher pulmonary dead-space fraction and surrogate indices such as ventilatory ratio (VR) also correlate with ARDS mortality [43-46]. VR is defined as [minute ventilation $\left.(\mathrm{mL} / \mathrm{min}) \times \mathrm{PaCO}_{2}(\mathrm{mmHg})\right] /[$ predicted body weight $\times 100 \times$ ideal $\left.\mathrm{PaCO}_{2}(\mathrm{mmHg})\right]$, where ideal $\mathrm{PaCO}_{2}$ is $37.5 \mathrm{mmHg}$. Whether dead-space fraction, $\mathrm{VR}$, or other physiologic measures are useful to guide 
Table 1 Definitions and severity classification for ARDS and PARDS

\begin{tabular}{|c|c|c|}
\hline Criteria & ARDS $^{\mathrm{a}}$ & PARDS $^{b}$ \\
\hline Timing & $\begin{array}{l}\text { Within } 7 \text { days of known clinical insult or new or worsening } \\
\text { respiratory symptoms }\end{array}$ & Within 7 days of known clinical insult \\
\hline Origin of edema & $\begin{array}{l}\text { Respiratory failure not fully explained by cardiac failure or } \\
\text { fluid overload. Objective assessment needed to exclude } \\
\text { hydrostatic edema if no risk factor present }\end{array}$ & $\begin{array}{l}\text { Respiratory failure not fully explained by cardiac failure or } \\
\text { fluid overload }\end{array}$ \\
\hline Chest imaging & $\begin{array}{l}\text { Bilateral opacities not fully explained by effusions, lobar/lung } \\
\text { collapse, or nodules }\end{array}$ & $\begin{array}{l}\text { New infiltrate(s) consistent with acute pulmonary paren- } \\
\text { chymal disease }\end{array}$ \\
\hline Age & Adult, no age cutoff specified & $\begin{array}{l}\text { Perinatal related lung disease is excluded. No age cutoff } \\
\text { specified }\end{array}$ \\
\hline \multicolumn{3}{|c|}{ Oxygenation and severity } \\
\hline Noninvasive & Included in mild ARDS & $\begin{array}{l}\text { Full face-mask bi-level ventilation or CPAP } \geq 5 \mathrm{cmH}_{2} \mathrm{O} \text { with } \\
\qquad \mathrm{PaO}_{2} / \mathrm{FiO}_{2} \leq 300 \text { or } \mathrm{SpO}_{2} / \mathrm{FiO}_{2} \leq 264\end{array}$ \\
\hline Mild & $200<\mathrm{PaO}_{2} / \mathrm{FiO}_{2} \leq 300$ with PEEP or CPAP $\geq 5 \mathrm{cmH}_{2} \mathrm{O}$ & $4 \leq \mathrm{Ol}<8$, or $5 \leq \mathrm{OSI} 7.5$ \\
\hline Moderate & $100<\mathrm{PaO}_{2} / \mathrm{FiO}_{2} \leq 200$ with $\mathrm{PEEP} \geq 5 \mathrm{cmH}_{2} \mathrm{O}$ & $8 \leq \mathrm{Ol}<16$, or $7.5 \leq \mathrm{OSI}<12.3$ \\
\hline Severe & $\mathrm{PaO}_{2} / \mathrm{FiO}_{2} \leq 100$ with $\mathrm{PEEP} \geq 5 \mathrm{cmH}_{2} \mathrm{O}$ & $\mathrm{OI} \geq 16$, or $\mathrm{OSI} \geq 12.3$ \\
\hline
\end{tabular}

ARDS, acute respiratory distress syndrome; CPAP, continuous positive airway pressure; OI, oxygenation index; OSI, oxygen saturation index; PARDS, pediatric acute respiratory distress syndrome; PEEP, positive end-expiratory pressure

a ARDS Berlin Definition [36]

b Pediatric Acute Lung Injury Consensus Conference definition [65]. Special considerations addressed for cyanotic heart disease, chronic lung disease, and left ventricular dysfunction

therapeutic selection is not well explored but has been advocated for consideration $[47,48]$.

Several investigators have advocated categorizing ARDS by respiratory mechanics [49-51]. Among the most promising measures are airway driving pressure (plateau airway pressure minus PEEP) [51] and transpulmonary pressure (airway minus pleural pressure) [52-54]. Both have intuitive appeal for quantifying overdistension and, for transpulmonary pressure, risk of end-expiratory airway closure and lung collapse $[40,55]$. Respiratory mechanics have value for guiding mechanical ventilation [56, 57], but whether they are useful for phenotyping ARDS for interventions unrelated to ventilator-induced lung injury (VILI) is less clear. One study did find that improved oxygenation in response to PEEP identified patients with better survival [58], but this strategy still requires prospective study.

Pediatric critical care clinicians have long recognized the inadequacies of adult based operational definitions for ARDS when applied to children [59, 60]. First, pediatric risk factors, etiologies, pathophysiology, and outcomes differ $[61,62]$. Second, $\mathrm{PaO}_{2}$ is measured less often, making the calculation of $\mathrm{PaO}_{2} / \mathrm{FiO}_{2}$ more challenging, since invasive arterial sampling is used more sparingly in children. Third, dissimilar ventilator modes are commonly used in children, and the oxygenation index $(\mathrm{OI})\left(\left[\mathrm{FiO}_{2} \times\right.\right.$ mean airway pressure $(\mathrm{Paw}) \times 100] / \mathrm{PaO}_{2}$ ) or oxygen saturation index (OSI) $\left(\left[\mathrm{FiO}_{2} \times \mathrm{Paw} \times 100\right] / \mathrm{SpO}_{2}\right)$ are primarily used to describe hypoxemia [63, 64]. The 2015 pediatric ARDS (PARDS) consensus [65] definition excludes infants with perinatal related lung disease, allows for unilateral or bilateral infiltrates, and requires OI or OSI to assess oxygenation during invasive ventilation, but criteria for edema origin and timing are similar to adult ARDS. The consensus definition delineates mild, moderate and severe PARDS based on OI or OSI for patients on mechanical ventilation, with no stratification for patients on non-invasive ventilation (Table 1).

The ongoing PROSpect trial (NCT03896763) is a twoby-two factorial, response-adaptive, randomized controlled clinical trial of supine vs. prone positioning and conventional mechanical ventilation vs. high-frequency oscillatory ventilation being conducted at 60 PICUs internationally. Up to 1000 participants will be enrolled and adaptive randomization will begin after data is collected for 400 subjects and will repeat every 100 patients thereafter. Any group demonstrating inferiority at a preplanned adaptive randomization update analysis will be eliminated to increase allocation to the superior group(s). The trial also includes sampling of plasma biomarkers which will make it potentially possible to identify treatment responsive subsets within each of the four treatment groups or within the PARDS patients overall that are enrolled in the trial.

\section{Chest radiography}

Radiographic methods have been used for identifying morphological phenotypes of ARDS that may respond differently to ventilator strategies and for assessing ARDS 
severity. Studies of the morphologic characteristics of radiographic lung infiltrates on computed tomography (CT) have identified two subgroups termed focal and non-focal ARDS that appear to have distinct lung physiology [66, 67]. Patients with non-focal ARDS have diffuse alveolar opacities on chest CT, whereas patients with focal ARDS have focal loss of aeration predominantly in the lower lobes and dependent regions. Based on the observation that the lungs of patients with nonfocal ARDS are significantly more recruitable than lungs of patients with focal ARDS, it is postulated that these radiographic subgroups may benefit from different ventilator strategies. Specifically, non-focal ARDS may benefit from a higher PEEP strategy with recruitment maneuvers to maximize recruitment of diffusely non-aerated lung. By contrast, focal ARDS may benefit from a lower PEEP strategy that minimizes overdistension of less affected regions of the lungs combined with proning to improve matching of ventilation to perfusion.

To test this hypothesis, European investigators designed the LIVE trial [68], a randomized clinical trial that compared personalization of ventilator settings according to $\mathrm{CT}$ assessment of lung morphology vs. standard $6 \mathrm{~mL} / \mathrm{kg}$ tidal volume, lower PEEP ventilation in 420 patients with moderate-to-severe ARDS. In the personalized ventilator arm, patients with non-focal ARDS received a tidal volume of $6 \mathrm{~mL} / \mathrm{kg}$, recruitment maneuvers and high PEEP, while those with focal ARDS received a tidal volume of $8 \mathrm{~mL} / \mathrm{kg}$, low PEEP, and prone position. In an intention-to-treat analysis, there was no difference in 90-day mortality between the groups. However, misclassification of patients as having focal or nonfocal ARDS occurred in $21 \%$ of patients, highlighting the difficulty of prospective assessment of ARDS phenotypes by CT. In a subgroup analysis, the 90-day mortality of the misclassified patients was significantly higher in the personalized group than in the standard ventilation group. This finding suggests that although tailoring mechanical ventilation to lung morphology might decrease mortality in correctly classified patients, misalignment of mode of mechanical ventilation and morphologic phenotype in ARDS may be particularly deleterious.

Plain chest radiographs have been studied as a tool to assess the extent of pulmonary edema in patients with ARDS and are more readily obtained than chest CTs in the critically ill. One group of investigators developed the Radiographic Assessment of Lung Edema (RALE) score to quantify both the extent and density of alveolar opacities by quadrant of the chest radiograph [69]. The RALE score provides a semiquantitative assessment of the extent of radiographic edema that has been validated against gravimetric measurement of lung edema in explanted lungs from organ donors. In patients with
ARDS enrolled in a randomized trial of conservative vs. liberal fluid management [70], higher RALE scores were independently associated with lower $\mathrm{PaO}_{2} / \mathrm{FiO}_{2}$ and worse survival. Conservative fluid management significantly decreased RALE score over 3 days compared with liberal fluid management. Two subsequent studies have confirmed that both the baseline RALE score and the change in RALE over time are associated with clinical outcomes in ARDS [71, 72]. Given the ready availability of chest radiographs, the RALE score may have value as a method for prognostic enrichment in clinical trials, in particular for trials that specifically target resolution of pulmonary edema, and could be complementary to assessment of lung mechanics at the bedside. How the RALE score relates to $C T$ assessment of diffuse vs. focal ARDS, and associated implications for personalizing treatment, remains unknown.

\section{Recent advances in protein biomarkers}

Several recent discoveries in protein biomarkers enable a better understanding of the pathophysiology of ARDS, improve prognostication and offer a possible route to precision-based care and assignment of phenotypes. Protein biomarkers in ARDS are most frequently studied in blood (usually plasma) or the air spaces of the lung (usually bronchoalveolar lavage fluid, BALF). Theoretically, BALF offers the advantage of studying injured lungs directly. Variance in specimen dilution secondary to exudative edema and/or acquisition procedures limits the standardisation of protein quantification in BALF [73]. Furthermore, the need for fiberoptic bronchoscopy also limits the routine clinical measurements of BALF protein biomarkers in ARDS [74, 75]. Less invasive sample acquisition using blind lavage or tracheal aspirates has been described; their relevance to corresponding BALF samples is uncertain [76]. In a recent innovation, investigators have studied proteins that were captured in the heat moisture exchanger filter in ventilated patients with ARDS; protein concentrations were reasonably well correlated with undiluted edema fluid samples (r2 0.8490.951) [77]. Further studies are needed to validate this non-invasive approach to study airspace biomarkers.

While most protein biomarkers have been confined exclusively to the research realm, alveolar type III procollagen peptide (PCP-III) is a compelling BALF protein candidate that has been associated with pathophysiology and outcomes in ARDS [78, 79]. In an observational study of 32 patients, alveolar PCP-III was highly sensitive (0.90) and specific (0.92) for diagnosing fibroproliferation in ARDS [80]. In a subsequent study, the same cutoff was associated with fibroproliferative changes on lung CT [81]. Further studies are underway to determine if PCP-III can be used to guide and test interventions with 
corticosteroids in ARDS (NCT\#03371498). In COVID19 , several routinely measured serum biomarkers, such as ferritin, CRP, and d-dimer, have been associated with prognosis. Currently, it is unclear whether these acutephase proteins are merely indicators of disease severity or offer opportunity for actionable interventions and/or are mechanistically informative. Further studies are needed to elucidate the precise role of these markers both in COVID-19 and non-COVID-19 ARDS.

Translation of biomarkers into the clinical domain has been challenging, in part due to the pursuit of a single discriminating biomarker that is continuously distributed in a heterogeneous clinical syndrome [82]. Investigators are increasingly applying machine learning algorithms to identify biologically discrete clusters of ARDS using multiple protein biomarkers [83]. A series of studies applying latent class analysis (LCA) used a combination of clinical data and plasma biomarkers to identify phenotypes in ARDS [18, 84-86]. Using this approach, hypo- and hyper-inflammatory phenotypes of ARDS were consistently identified across five RCTs, and these phenotypes exhibited divergent biological characteristics, clinical features and outcomes. The hyper-inflammatory phenotype was associated with exaggerated inflammation with elevated plasma levels of IL-8, IL-6, and sTNFR-1. Levels of PAI-1 were also higher in this phenotype, whereas protein $C$ was lower. Mortality at day 90 was approximately twofold higher in the hyper-inflammatory phenotype across all cohorts. Importantly, in three of the trials, differential treatment responses were observed in the phenotypes with improved outcomes in the treatment arm for patients in the hyperinflammatory subgroup $[18,84$, 85]. None of the original trials showed a mortality benefit [70, 87, 88]. In related work, a group of Dutch investigators applied cluster analysis to plasma protein biomarker data from ARDS patients and identified two phenotypes, which they termed "reactive" and "uninflamed"; these phenotypes have prognostic value as well, though how they correspond to the LCA-phenotypes remains unknown [89].

One challenge of implementing these approaches clinically is the difficulty of identifying these phenotypes at the bedside. LCA models are complex, comprising 30-40 variables that are not amenable for prospective use. To address this challenge, investigators have developed 3-variable (IL-8, bicarbonate and protein $\mathrm{C}$ ) and 4-variable (addition of vasopressor) parsimonious models that accurately classified the two LCA phenotypes in an independent validation cohort (area under the curve: 0.94 and 0.95, respectively) [86]. Importantly, when one of the ancillary parsimonious models was applied to the HARP-2 study, a randomized clinical trial that tested the efficacy of simvastatin vs. placebo, a survival benefit was observed in

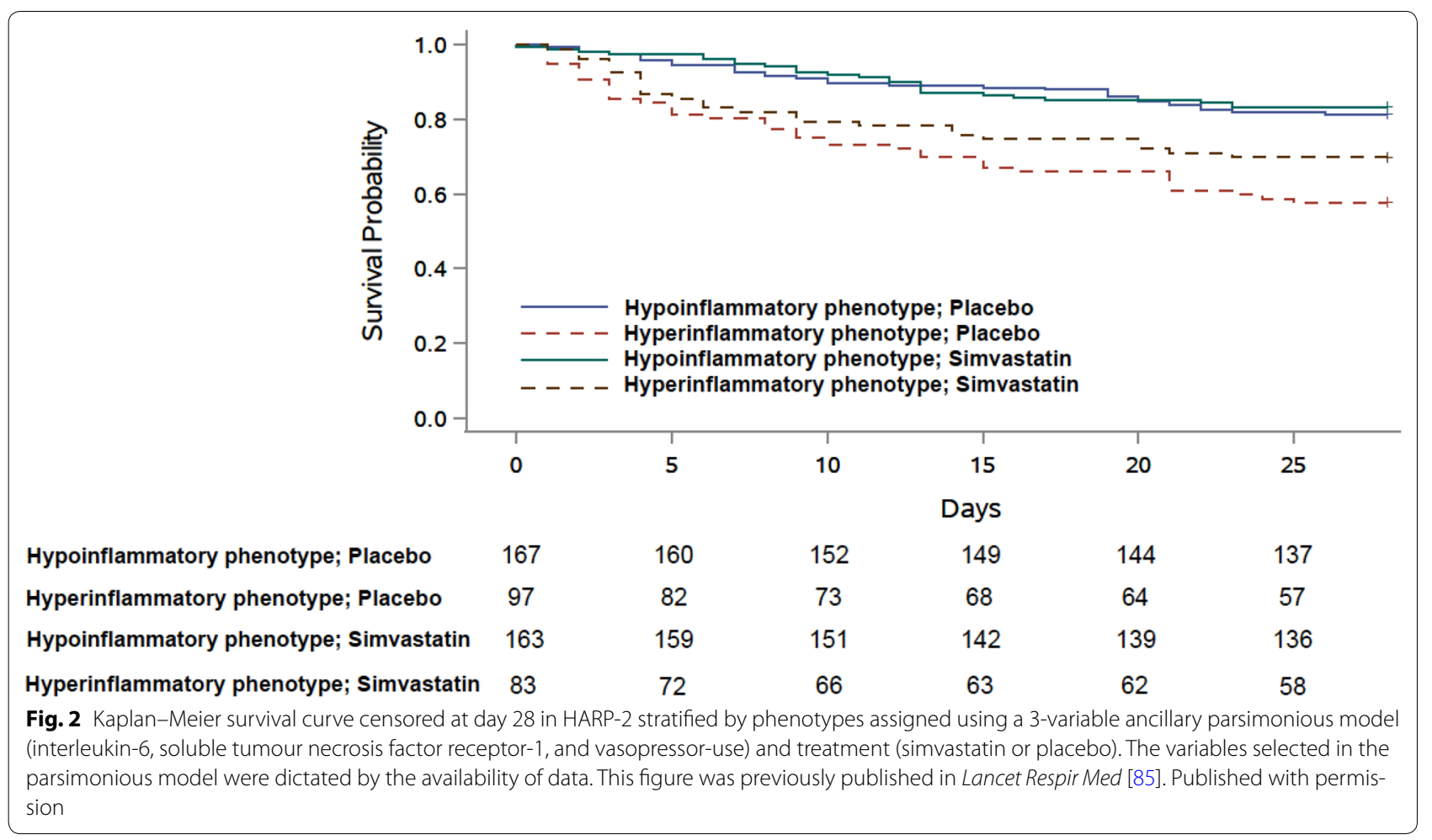


the hyperinflammatory phenotype at day 28 (Fig. 2). The inability to quantify protein biomarkers rapidly at the bedside is another challenge. Recently, in a preliminary report in patients with COVID-19 ARDS, the same investigators quantified IL- 6 and sTNFR-1 using a novel point-of-care assay (Evidence Multistat Analyser; Randox Laboratories, Country Antrim, UK) [90]. The assay results were used to assign ARDS phenotype based on the parsimonious model, demonstrating the feasibility of phenotype-classification in real-time. In summary, these studies indicate that the application of biomarkers for clinical trials and/or decision-making may soon be plausible.

\section{Gene expression}

Gene expression from leukocytes can be used to acquire a snapshot image of the immune response. An advantage of transcriptomics over protein biomarkers is that nucleic acid-based arrays cover tens of thousands of genes and, therefore, provide a more comprehensive overview than the measurement of a limited number of proteins. The major disadvantage is that relative quantification of messenger RNA does not provide direct information on a number of transcribed proteins and may, therefore, not directly reflect the functional landscape in organ injury. In addition, it is challenging to translate gene expression to a point of care assay. Peripheral blood transcriptomics has been used to subphenotype patients with sepsis resulting in the identification of two to four subphenotypes with clear differences in immune exhaustion, innate immune response, T-cell balance and coagulation [91-94].

In ARDS, such an approach has not been tried. Gene expression profiles of peripheral leukocytes were, however, compared between ARDS patients who were classified as having a "reactive" or "uninflamed" subphenotype based on a set of 20 plasma biomarkers of inflammation, coagulation and endothelial injury, as described above [95]. Approximately $30 \%$ of all genes were differentially expressed between these subphenotypes. Genes associated with neutrophil activation were enriched in the "reactive" subphenotype, which is consistent with the activated innate immune response suggested by increased interleukin- 8 and interleukin-6 protein concentrations in this subgroup. However, there was low agreement between subphenotype allocation based on plasma proteins and sepsis subphenotypes informed by blood leukocyte expression profiles. It should be noted that any measurement in blood reflects systemic host response, which is influenced by several processes other than ARDS, as lung injury often does not develop in isolation (Fig. 1). Thus, another study involving 16 patients with ARDS focused on paired measurements of gene expression of alveolar macrophages (AMs) and peripheral blood monocytes (PBMs) [96]. This research group found highly divergent patterns of expression between AMs and PBMs. Enrichment of immunoinflammatory gene sets in AMs was associated with better clinical outcomes, but with worse clinical outcomes in PBMs. Further studies of both the lung and the systemic circulation in ARDS patients will likely provide more insights into the mechanisms of both lung and non-pulmonary organ injury that are relevant for classical ARDS and COVID19 ARDS (Fig. 3).

\section{Microbiology}

Bacterial and viral infections of the lung are the most common etiologies associated with ARDS [97]. The causative pathogens differ from ARDS secondary to community-acquired pneumonia (CAP) or hospital-acquired and ventilator-associated pneumonia (HAP/VAP) [98, 99]. Pathogens differ also according to age and the presence of co-morbid conditions, prior colonization, exposure history and vaccination status. The treatment of a specific infection is a pre-requisite for standard of care and would seem to be a necessary part of any precision medicine approaches in ARDS. However, making the diagnosis of specific infections in ARDS can be challenging and involves standard and new methods and may inform specific phenotype designations in the future.

The typical diagnostic approach for ARDS secondary to CAP or HAP/VAP includes blood cultures and Gram stain and culture of respiratory specimens (expectorated sputum or tracheal aspirate), ideally obtained before commencement of antimicrobial therapy [98, 99]. However, the yield of traditional cultures for detecting organisms is generally low (30-50\%) and varies according to organism, receipt of prior antimicrobial therapy, and setting [98].

The use of invasive respiratory sampling (ie, bronchoalveolar lavage [BAL], protected specimen brush [PSB]) and blind bronchial sampling [ie, mini-BAL]) leads to higher yield in identifying pathogens compared to traditional microbiologic tests of tracheal aspirate or sputum examination. However, even with invasive respiratory sampling, a high percentage of patients with ARDS remain with no identified organisms [97]. In addition, studies on VAP did not demonstrate an outcome benefit on the routine use of invasive sampling with quantitative cultures compared to noninvasive sampling with quantitative cultures. Invasive respiratory sampling should be performed in immunocompromised patients, in the presence of unexplained, persistent or worsening infiltrates.

Nucleic acid detection tests (NATs), such as polymerase chain reaction (PCR), are becoming available to 


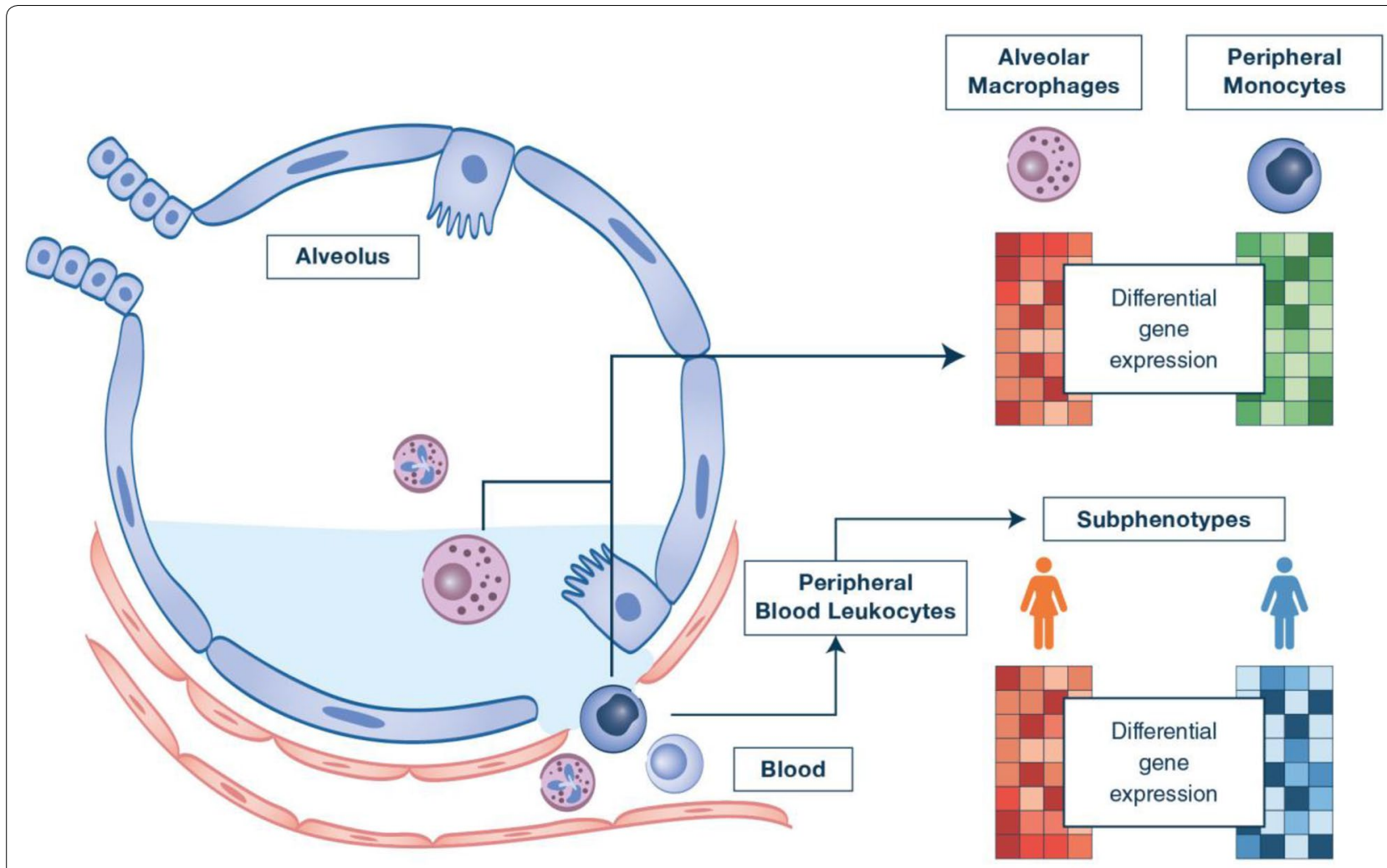

Fig. 3 Differences in peripheral leukocyte gene expression have been used to identify ARDS subphenotypes. The plasma and alveoli represent distinct compartments, as direct comparison of peripheral monocytes and alveolar macrophages has also shown profound differences in gene expression

detect several pathogens including Mycoplasma spp., Chlamydia pneumoniae and Bordetella pertussis as well as common bacteria such as Staphylococcus aureus and Streptococcus pneumoniae. In one study, molecular testing for 26 bacterial and viral pathogens of single lower respiratory tract specimens achieved pathogen detection in $87 \%$ of CAP patients compared with $39 \%$ with culturebased methods [100]. Of these, $78 \%$ had a bacterial pathogen detected by PCR but only $32 \%$ were culture-positive [100]. Legionella and Pneumococcal Urinary Antigen can be used in patients with ARDS due to CAP [98].

With the increasing use of NATs, viral pathogens are increasingly detected among critically ill adult patients with respiratory illness, with a reported prevalence between $17 \%$ to $53 \%$ of patients [101]. Detecting viruses in respiratory specimens does not always establish causality with ARDS [102]. However, it is generally believed that most respiratory viruses may cause ARDS, especially in the elderly, the immunocompromised, patients with other co-morbid conditions, and occasionally in previously healthy individuals [103]. While the role of routine testing of PCR panels for respiratory viruses has not been established, testing for influenza with PCR is recommended when influenza is circulating in the community; this test is preferred over other rapid influenza diagnostic tests (i.e., antigen test) [98]. Other uncommon but important endemic pathogens should also be considered in the presence of history of travel, residence in certain geographic locations or history of specific exposures (Table 2).

Next generation sequencing (NGS) techniques have increased our ability to detect pathogens and possibly to detect novel pathogens [104-108]. At present they have limited clinical use, but they have the potential to change our understanding of ARDS epidemiology. Next-generation sequencing techniques may in the future enable pathogen identification using blood samples without the need for invasive respiratory sampling $[109,110]$.

In the last two decades, several ARDS pandemics have been due to emerging viral pathogens. The 2009 H1N1 pandemic was caused by a novel influenza A virus (H1N1pdm09 virus), and since then, the virus has circulated seasonally around the world. Novel coronaviruses have been responsible for three pandemics causing Severe Acute Respiratory Syndrome (SARS), Middle East Respiratory Syndrome (MERS) and the ongoing 
Table 2 Common, pandemic, and endemic pathogens responsible for ARDS and their features and risk factors

\section{Features and risk factors}

\section{Common pathogens}

\begin{tabular}{|c|c|}
\hline $\begin{array}{l}\text { Streptococcus pneumoniae, Staphylococcus aureus, Haemophilus influenzae, } \\
\text { Moraxella catarrhalis, Legionella pneumophila, Chlamydia pneumonia, } \\
\text { Mycoplasma pneumonia }\end{array}$ & $\begin{array}{l}\text { Community-acquired pneumonia } \\
\text { Co-morbid conditions* } \\
\text { Influenza active in community (Streptococcus pneumoniae, Staphylococcus } \\
\text { aureus, Haemophilus influenzae) } \\
\text { Cruise ships or resorts (Legionella pneumophila) }\end{array}$ \\
\hline $\begin{array}{l}\text { Pseudomonas aeruginosa, Klebsiella pneumoniae, Escherichia coli, Acineto- } \\
\text { bacter species, Enterobacter species }\end{array}$ & $\begin{array}{l}\text { Hospital-acquired pneumonia } \\
\text { Co-morbid conditions* } \\
\text { Mechanical ventilation }\end{array}$ \\
\hline Anaerobes & Aspiration \\
\hline Influenza A or B virus & $\begin{array}{l}\text { Influenza A can cause pandemics } \\
\text { Co-morbid conditions* } \\
\text { Influenza active in community }\end{array}$ \\
\hline $\begin{array}{l}\text { Picornaviruses (rhinovirus, enterovirus), Human coronaviruses (229E, NL63, } \\
\text { OC43, HKU1), Respiratory syncytial virus, Human metapneumovirus, } \\
\text { Parainfluenza (1-4), Adenoviruses }\end{array}$ & $\begin{array}{l}\text { Frequently detected in critically ill patients with ARDS } \\
\text { May cause disease in the elderly and in patients with co-morbid condi- } \\
\text { tions* }\end{array}$ \\
\hline Pneumocystis jirovecii & HIV infection or other causes of immunosuppression \\
\hline \multicolumn{2}{|l|}{ Pandemic pathogens } \\
\hline SARS-CoV-2 & $\begin{array}{l}\text { Pandemic situation } \\
\text { Exposure to patient with known COVID-19 } \\
\text { Residence or travel in an area with active COVID-19 }\end{array}$ \\
\hline \multicolumn{2}{|l|}{ Endemic pathogens } \\
\hline Bacillus anthracis (anthrax) & In context of bioterrorism \\
\hline Yersinia pestis (pneumonic plague) & $\begin{array}{l}\text { Residence in rural areas in Madagascar } \\
\text { Camping, hunting or contact with rodents }\end{array}$ \\
\hline Francisella tularensis (tularemia) & Exposure to rabbits \\
\hline Chlamydophila psittaci (psittacosis) & Exposure to birds and poultry/poultry market \\
\hline Coxiella burnetti (Q fever) & Exposure to farm animals or parturient cats \\
\hline Mycobacterium tuberculosis & $\begin{array}{l}\text { Residence in tuberculosis endemic areas } \\
\text { Co-morbid conditions: Alcoholism, injection drug use, HIV infection, } \\
\text { immunosuppression }\end{array}$ \\
\hline Avian influenza A/H5N1, A/H5N6, A/H7N9 and other subtypes & $\begin{array}{l}\text { Residence or travel to Southeast and East Asia } \\
\text { Exposure to birds and poultry/poultry market }\end{array}$ \\
\hline MERS-COV & $\begin{array}{l}\text { Residence or travel to the Arabian Peninsula } \\
\text { Exposure to dromedary camel }\end{array}$ \\
\hline Hantaviruses (e.g., Sin Nombre, Andes) & $\begin{array}{l}\text { Residence or travel to Western and Southwestern United States } \\
\text { Exposure to rodent excretions }\end{array}$ \\
\hline Measles virus & Incomplete vaccination \\
\hline Human adenovirus type 55 (HAdV-55) & Residence or travel to Southeast and East Asia \\
\hline Varicella-zoster virus & $\begin{array}{l}\text { Pregnancy } \\
\text { Immunosuppression }\end{array}$ \\
\hline Cytomegalovirus & Immunosuppression \\
\hline Blastomyces dermatitidis, Histoplasma capsulatum, Coccidioides immitis & $\begin{array}{l}\text { Residence or travel to Ohio and Mississippi River valleys and Great Lakes } \\
\text { (Blastomyces dermatitidis, Histoplasma capsulatum) or Western and south- } \\
\text { western United States (Coccidioides immitis) } \\
\text { Outdoor activities in wooded areas (Blastomyces dermatitidis) }\end{array}$ \\
\hline Plasmodium falciparum & Residence or travel to malaria endemic areas \\
\hline
\end{tabular}

${ }^{*}$ Co-morbid conditions include alcoholism, COPD, aspiration, pregnancy, bronchiectasis, injection drug use, HIV infection, and immunosuppression

COVID-19. The latter syndrome is caused by the SARS$\mathrm{CoV}-2$, which has $75-80 \%$ genomic similarity to the severe acute respiratory syndrome coronavirus (SARS$\mathrm{CoV}), 50 \%$ to the Middle East Respiratory syndrome coronavirus (MERS-CoV), and $96 \%$ to a bat coronavirus
[111-113]. COVID-19 was first reported in December 2019, in Wuhan, Hubei Province, China [111, 114, 115]. It then spread worldwide, infecting over 54 million people to date to become the largest pandemic in modern history. 


\section{Timing of interventions}

Clinical trials have established the benefit of lung protective ventilation and a conservative strategy of fluid management in the treatment of ARDS [57, 70]. Pharmacologic therapies have failed to improve survival [17, 116-119], although there is evidence that dexamethasone is beneficial for COVID-19 ARDS and may have benefit in classical non-COVID-19 ARDS [32, 34, 120]. Given the lack of effective treatments once lung injury has progressed to ARDS, the approach to ARDS management has been reframed to also incorporate identification and treatment of patients at risk for ARDS or in the early stages of lung injury. There has been a shift towards categorizing patients into one of three stages of lung injury - presence of risk factors such as sepsis or pneumonia, early acute lung injury, and ARDS - and modifying their treatment accordingly (Fig. 4). Personalized approaches to ARDS trials or treatment will need to consider the timing of the intervention, as the clinical and biological phenotype of ARDS evolves rapidly over the first few hours to days of illness.

\section{Prevention of lung injury}

Since it was first hypothesized that ARDS could be prevented, some studies focused on preventing lung injury in at-risk patients. In theory, prevention might work if the therapeutic had a low risk of harm and might actually reduce the development of ARDS. It was thought that there might be a role for aspirin in preventing ARDS [121], but a phase $2 \mathrm{~b}$ trial found that the use of aspirin did not reduce the risk of ARDS [122]. A recent randomized controlled trial showed no benefit of early vitamin D3 supplementation among critically ill, vitamin D-deficient patients [123]. The NHLBI-funded Prevention and Early Treatment of Acute Lung Injury (PETAL) network is currently enrolling patients with septic shock in a randomized phase 3 trial, Crystalloid Liberal or Vasopressors Early Resuscitation in Sepsis (CLOVERS), testing the impact of a restrictive fluids strategy (early vasopressors followed by rescue fluids) compared to a liberal fluid strategy (early fluids followed by rescue vasopressors) in patients with sepsis-induced hypotension (NCT03434028) on the development of ARDS and 28-day mortality. Another trial that may launch in the near future is Acetaminophen and Ascorbate in Sepsis:

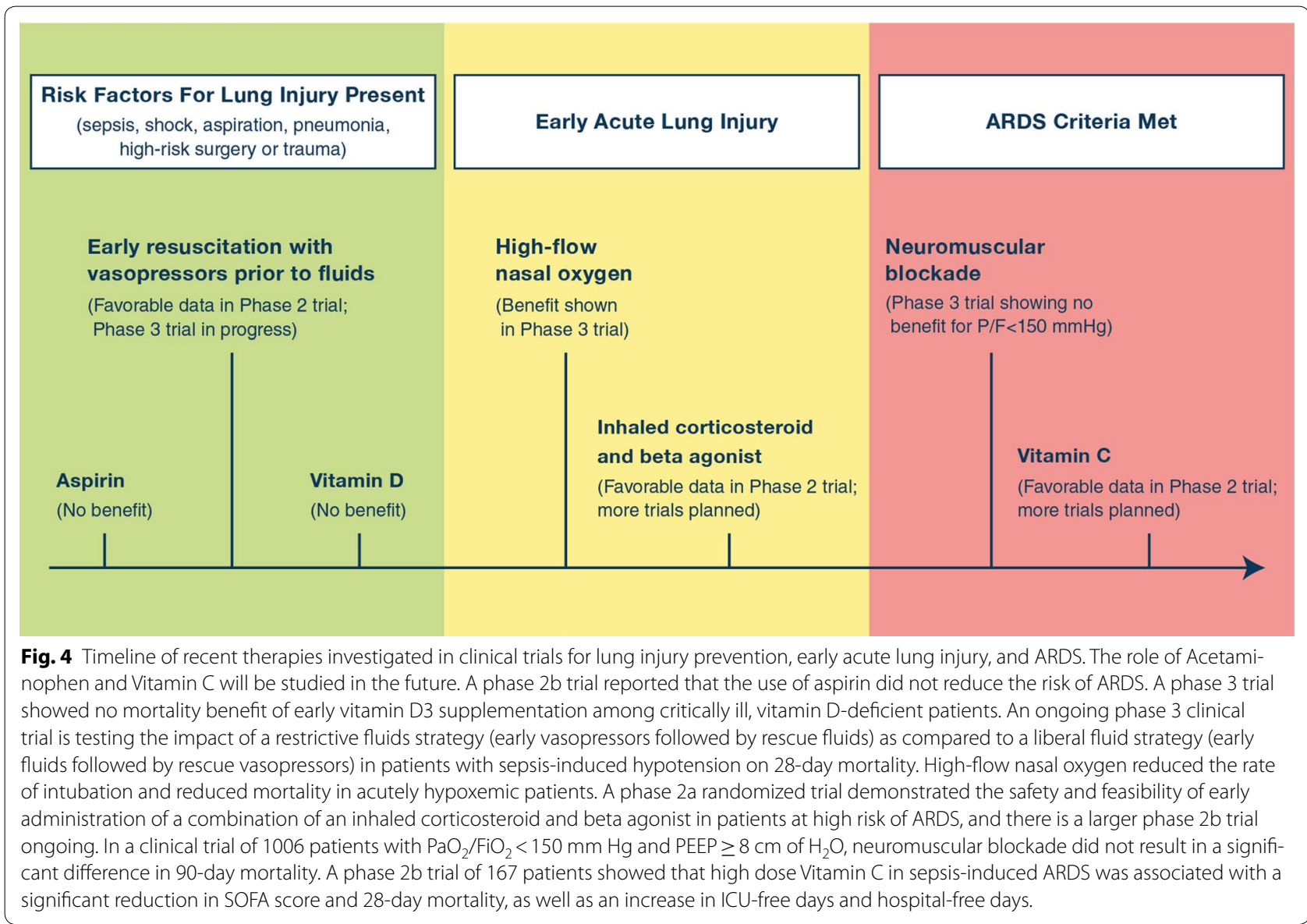


Targeted Therapy to Enhance Recovery (ASTER) for testing the effects of acetaminophen and high dose intravenous vitamin $\mathrm{C}$ on both pulmonary and non-pulmonary organ dysfunction in early sepsis (NCT04291508). This trial may help to identify specific sepsis responsive phenotypes prior to the development of ARDS. For example, the trial will measure plasma free hemoglobin to test if it will enrich for the development of more organ failure, including ARDS, from early sepsis. Also, if acetaminophen shows efficacy especially in patients with elevated plasma hemoglobin, then this assay could be incorporated as a method for predictive enrichment in future trials that target the pro-oxidant effects of plasma free hemoglobin.

\section{Treatment of early acute lung injury}

Another growing interest has been to prevent progression of acute lung injury in patients who do not yet meet criteria for ARDS. Since the initial lung injury prevention score (LIPS) study, investigators have tried to identify early acute lung injury prior to the onset of respiratory failure that requires positive pressure ventilation [124]. A three-component early acute lung injury score incorporating oxygen requirement, respiratory rate, and immune suppression accurately identified patients who progressed to ARDS with an area under the curve of 0.86 , a similar performance to the LIPS. Patients received one point for an oxygen requirement $>2-6 \mathrm{~L} / \mathrm{min}$ or 2 points for an oxygen requirement $>6 \mathrm{~L} / \mathrm{min}$, one point each for a respiratory rate $>30 / \mathrm{min}$ and one point for immune suppression [125]. In this study, the median time of progression from meeting criteria for early acute lung injury to ARDS was $20 \mathrm{~h}$, suggesting a window for intervention. In line with the concept of selecting patients in early sepsis at risk for ARDS by respiratory as well as hemodynamic criteria, the above discussed ASTER trial will enroll patients who require $\geq 6 \mathrm{~L}$ nasal oxygen or vasopressors for shock.

In 2015 a multicenter French trial compared high-flow nasal oxygen, non-invasive face mask ventilation, and standard oxygen therapy in patients in the emergency department with acute hypoxemic respiratory failure, primarily from pneumonia. The results indicated that high-flow nasal oxygen reduced the rate of endotracheal intubation in patients who presented with $\mathrm{PaO}_{2} /$ $\mathrm{FiO}_{2} \leq 200 \mathrm{~mm} \mathrm{Hg}$ and reduced mortality in the entire cohort of 310 acutely hypoxemic patients with $\mathrm{PaO}_{2} /$ $\mathrm{FiO}_{2} \leq 300 \mathrm{~mm} \mathrm{Hg}$ [126]. This was a pivotal trial that has changed clinical practice worldwide for critically ill patients. This is also an excellent example of how to test new interventions in the early phases of acute lung injury prior to the development of ARDS by Berlin criteria.
On a smaller scale, a Phase 2a randomized trial demonstrated the safety and feasibility of early administration of a combination of an inhaled corticosteroid and beta agonist in 61 patients at high risk of ARDS [127]. Treated patients demonstrated greater longitudinal improvement in $\mathrm{SpO}_{2} / \mathrm{FiO}_{2}$. An ongoing clinical trial, ARrest RESpiraTory Failure From PNEUMONIA (ARREST PNEUMONIA), is testing the effects of a combination of an inhaled corticosteroid and a beta agonist in preventing progression to acute respiratory failure among patients who present with pneumonia and hypoxemia (NCT04193878). This therapeutic approach would likely have low value for established ARDS based on prior negative trials, but has more promise in the early phase of acute lung injury. Thus, personalized medicine needs to consider the optimal timing to test a new intervention.

\section{Treatment of ARDS}

There has also been promising new work to test therapies for patients with established ARDS. A phase $2 b$ trial of high dose vitamin $C$ in sepsis-induced ARDS demonstrated a significant difference in the primary outcome of Sequential Organ Failure Assessment score at $96 \mathrm{~h}$ [128]. In addition, the Vitamin $C$ treated patients had a significant reduction in 28-day mortality and an increase in ICU-free days, and hospital-free days [16].

To enrich prognostically for the potential efficacy of neuromuscular blockade, the ACURASYS phase 3 trial required patients to be enrolled with moderate to severe hypoxemia ( $\mathrm{Pa} 02 / \mathrm{Fi} 02<150 \mathrm{mmHg}$ ) and the results showed a lower mortality in the patients treated with neuromuscular blockade [38]. This prospective trial was designed on the basis of a phase 2 trial that suggested the value of this cut-off for a phase 3 trial [129]. However, the positive results of the phase 3 trial were not widely adopted and, therefore, a new trial, Reevaluation Of Systemic Early Neuromuscular Blockade (ROSE), was carried out to reassess this therapy. This phase 3 trial enrolled 1006 patients and found that there was no mortality benefit to early continuous neuromuscular blockade compared to usual care with lighter sedation goals in patients with moderate-to-severe ARDS [39]. The different results in the ROSE trial might be explained by the higher PEEP strategy, lighter sedation in the control group, and earlier enrollment in the more recent trial than in the ACURASYS trial $[38,39]$. These two trials emphasize how phenotypes for personalized medicine can be selected on the basis of a physiologic abnormality, in this case the severity of arterial hypoxemia, when the goal is to test the therapy in a patient population most likely to respond to the treatment. In the future, prognostic enrichment for trials such as these may be amplified by including measures of lung compliance, radiographic 
extent of pulmonary edema, and plasma biologic markers as well. As discussed below, these trials did not include patient groups to prove that non-responders would be those with a P/F $>150 \mathrm{mmHg}$, but they nevertheless did prospectively identify an ARDS population that might respond more effectively to the proposed therapy.

\section{Conclusions and future challenges}

Each of the sections in this review has identified several factors that contribute to heterogeneity in patients with ARDS. These variables include the associated clinical risk factor (pneumonia vs. non-pulmonary sepsis vs. trauma) or the combination of contributing clinical factors (blood transfusions, shock), the degree of physiologic lung injury graded by hypoxemia or impaired carbon dioxide excretion, variability in the extent of pulmonary opacities and lung edema on chest imaging, the range of biologic profiles as indicated by plasma protein biomarkers and gene expression in the blood, and the diverse number of pathogens that can initiate ARDS, including bacteria, viruses, fungi and parasites. How to best integrate these various dimensions of complexity into trials testing novel therapies for ARDS is understandably challenging, especially when one must consider whether the therapy will be tested in the early phase of lung injury prior to positive pressure ventilation, as was the case with high flow nasal oxygen, or once ARDS is established as in trials of neuromuscular blockade.

Importantly, different approaches to "personalization" will likely be required for different treatments; the key question will be how to best select potential patients for the therapeutic at hand. In many cases, it will not be feasible to determine the best personalization method in advance; particularly for trials of novel pharmacotherapies, counter-intuitive results may emerge [130], and/or our understanding of biology in specific phenotypes may be incomplete or frankly incorrect [131]. Instead, trials in broader ARDS populations will often need to be conducted first, with pre-specified plans for stratified analyses by phenotype, followed by dedicated smaller trials in phenotypes that seem to respond. Such an approach is consistent with US FDA guidance for enrichment in clinical trials, which stipulates that it is important to identify both responders and non-responders within a given condition before concluding that a therapy has benefits for a particular subgroup.

Clearly some therapies have been successful in randomized clinical trials without focusing on specific ARDS sub-groups. Lung protective ventilation [57] and fluid conservative therapy [70] were effective when applied to most patients with ARDS. However, these successes are the exception rather than the rule, and new approaches are increasing the feasibility of testing new therapies in a more personalized approach. For example, recent evidence indicates success with real time measurements of two plasma biomarkers in ARDS, making it more feasible to incorporate sub-phenotypes in clinical trials [90]. Physiologic variables such as the ventilatory ratio could be used to select patients for trials that had a high likelihood to improve pulmonary blood flow and reduce pulmonary dead space, similar to what was achieved in a trial of activated protein $C$ for ARDS from non-sepsis causes in which pulmonary dead space was reduced with this anti-coagulant and anti-inflammatory therapy [132]. This approach could be used to assess the effects of therapies that target lung vascular injury and neutrophil endothelial complexes and reduce microvascular injury and enhance capillary blood flow to the lung [133, 134].

The current global pandemic of ARDS related to SARS$\mathrm{CoV}-2$ demonstrates the potential of a more focused approach to ARDS clinical trials. Corticosteroids appear to be effective for patients with COVID-19 associated ARDS, in contrast to many prior studies of corticosteroids for ARDS which had conflicting findings, demonstrating the value of enriching for a specific clinical phenotype [32]. In the future, progress with specific biologic therapeutics for ARDS such as statins or other antiinflammatory treatments could benefit from enrichment with some of the variables considered in this review to maximize their chance of efficacy.

\section{Author details \\ ${ }^{1}$ Department of Anesthesia, University of California San Francisco, San Fran- cisco, CA, USA. ${ }^{2}$ Cardiovascular Research Institute, University of California, San Francisco, USA. ${ }^{3}$ Division of Pulmonary and Critical Care Medicine, Depart- ment of Medicine, University of California, San Francisco, USA. ${ }^{4}$ King Saud Bin Abdulaziz University for Health Sciences and King Abdullah International Medical Research Center, Riyadh, Saudi Arabia. ${ }^{5}$ Division of Allergy, Pulmonary and Critical Care, Vanderbilt University Medical Center, Nashville, TN, USA. \\ ${ }^{6}$ Department of Respiratory Medicine, Amsterdam University Medical Centers, Location AMC, University of Amsterdam, Infection and Immunity, Amsterdam, The Netherlands. ${ }^{7}$ Department of Anesthesiology, Washington University, Saint Louis, MO, USA. ${ }^{8}$ Division of Pulmonary, Allergy, and Critical Care Medicine, Center for Acute Respiratory Failure, Columbia University College of Physicians and Surgeons, New York, NY, USA. ${ }^{9}$ School of Nursing, University of Pennsylvania, Philadelphia, PA, USA. ${ }^{10}$ Department of Anesthesia and Criti- cal Care, La Pitié Salpetriere Hospital, University Paris-Sorbonne, Paris, France. ${ }^{1}$ Department of Medicine, Stanford University, Stanford, CA, USA.}

\section{Acknowledgements}

This work was funded by the National Institutes of Health (Grant numbers HL123004, HL134828, 5TL1TR001871-05, HL14722, K23 HL133489, HL145506, UH3HL141736, HL140026, 5T32GM008440-24, and HL126176).

\section{Compliance with ethical standards}

Conflicts of interest

The authors have no conflicts of interest for this manuscript.

\section{Publisher's Note}

Springer Nature remains neutral with regard to jurisdictional claims in published maps and institutional affiliations. 
Received: 13 September 2020 Accepted: 13 October 2020

Published online: 18 November 2020

\section{References}

1. Matthay MA, Zemans RL, Zimmerman GA, Arabi YM, Beitler JR, Mercat A, Herridge M, Randolph AG, Calfee CS (2019) Acute respiratory distress syndrome. Nat Rev Dis Primers 5:18

2. Beigel JH, Tomashek KM, Dodd LE, Mehta AK, Zingman BS, Kalil AC, Hohmann E, Chu HY, Luetkemeyer A, Kline S, Lopez de Castilla D, Finberg RW, Dierberg K, Tapson V, Hsieh L, Patterson TF, Paredes R, Sweeney DA, Short WR, Touloumi G, Lye DC, Ohmagari N, Oh MD, Ruiz-Palacios GM, Benfield T, Fatkenheuer G, Kortepeter MG, Atmar RL, Creech CB, Lundgren J, Babiker AG, Pett S, Neaton JD, Burgess TH, Bonnett T, Green M, Makowski M, Osinusi A, Nayak S, Lane HC, Members A-SG, (2020) Remdesivir for the Treatment of Covid-19 - Final Report. N Engl J Med

3. Guerin C, Reignier J, Richard JC, Beuret P, Gacouin A, Boulain T, Mercier E, Badet M, Mercat A, Baudin O, Clavel M, Chatellier D, Jaber S, Rosselli S, Mancebo J, Sirodot M, Hilbert G, Bengler C, Richecoeur J, Gainnier M, Bayle F, Bourdin G, Leray V, Girard R, Baboi L, Ayzac $L$, Group PS (2013) Prone positioning in severe acute respiratory distress syndrome. N Engl J Med 368:2159-2168

4. Ware LB, Matthay MA, Mebazza A (2020) Designing an ARDS trial for 2020 and beyond. Intensive Care Med. https://doi.org/10.1007/s0013 4-020-06232-x

5. Bellani G, Laffey JG, Pham T, Fan E, Brochard L, Esteban A, Gattinoni L, van Haren F, Larsson A, McAuley DF, Ranieri M, Rubenfeld G, Thompson BT, Wrigge H, Slutsky AS, Pesenti A, LS Investigators, Group ET ( 201) Epidemiology, patterns of care, and mortality for patients with acute respiratory distress syndrome in intensive care units in 50 countries. JAMA 315:788-800

6. Khemani RG, Smith L, Lopez-Fernandez YM, Kwok J, Morzov R, Klein MJ, Yehya N, Willson D, Kneyber MCJ, Lillie J, Fernandez A, Newth CJL, Jouvet P, Thomas NJ (2019) Paediatric acute respiratory distress syndrome incidence and epidemiology (PARDIE): an international, observational study. Lancet Respir Med 7:115-128

7. Rubenfeld GD, Caldwell E, Peabody E, Weaver J, Martin DP, Neff M, Stern EJ, Hudson LD (2005) Incidence and outcomes of acute lung injury. N Engl J Med 353:1685-1693

8. Linko R, Okkonen M, Pettila V, Perttila J, Parviainen I, Ruokonen E, Tenhunen J, Ala-Kokko T, Varpula T, FINNALI-study group (2009) Acute respiratory failure in intensive care units. FINNALI: a prospective cohort study. Intensive Care Med 35:1352-1361

9. Butt YM, Smith ML, Tazelaar HD, Vaszar LT, Swanson KL, Cecchini MJ, Boland JM, Bois MC, Boyum JH, Froemming AT, Khoor A, Mira-Avendano I, Patel A, Larsen BT (2019) Pathology of vaping-associated lung injury. N Engl J Med 381:1780-1781

10. Layden JE, Ghinai I, Pray I, Kimball A, Layer M, Tenforde MW, Navon L, Hoots B, Salvatore PP, Elderbrook M, Haupt T, Kanne J, Patel MT, Saathoff-Huber L, King BA, Schier JG, Mikosz CA, Meiman J (2020) Pulmonary illness related to E-cigarette use in illinois and Wisconsin-final report. N Engl J Med 382:903-916

11. Matsumoto $S$, Fang $X$, Traber MG, Jones KD, Langelier C, Hayakawa Serpa P, Calfee CS, Matthay MA, Gotts JE (2020) Dose-dependent pulmonary toxicity of aerosolized vitamin E acetate. Am J Respir Cell Mol Biol. https://doi.org/10.1165/rcmb.2020-02090C

12. Hamilton BC, Kukreja J, Ware LB, Matthay MA (2017) Protein biomarkers associated with primary graft dysfunction following lung transplantation. Am J Physiol Lung Cell Mol Physiol 312:L531-L541

13. Bhattacharya M, Kallet RH, Ware LB, Matthay MA (2016) Negativepressure pulmonary edema. Chest 150:927-933

14. Sue RD, Matthay MA, Ware LB (2004) Hydrostatic mechanisms may contribute to the pathogenesis of human re-expansion pulmonary edema. Intensive Care Med 30:1921-1926

15. Sheu CC, Gong MN, Zhai R, Chen F, Bajwa EK, Clardy PF, Gallagher DC, Thompson BT, Christiani DC (2010) Clinical characteristics and outcomes of sepsis-related vs non-sepsis-related ARDS. Chest 138:559-567
16. Fowler AA III, Truwit JD, Hite RD, Morris PE, DeWilde C, Priday A, Fisher B, Thacker LR II, Natarajan R, Brophy DF, Sculthorpe R, Nanchal R, Syed A, Sturgill J, Martin GS, Sevransky J, Kashiouris M, Hamman S, Egan KF, Hastings A, Spencer W, Tench S, Mehkri O, Bindas J, Duggal A, Graf J, Zellner S, Yanny L, McPolin C, Hollrith T, Kramer D, Ojielo C, Damm T, Cassity E, Wieliczko A, Halquist M (2019) Effect of vitamin C infusion on organ failure and biomarkers of inflammation and vascular injury in patients with sepsis and severe acute respiratory failure: the CITRIS-ALI randomized clinical trial. JAMA 322:1261-1270

17. The National Heart, Lung, and Blood Institute ARDS Clinical Trials Network (2014) Rosuvastatin for sepsis-associated acute respiratory distress syndrome. N Engl J Med 370:2191-2200

18. Calfee CS, Delucchi K, Parsons PE, Thompson BT, Ware LB, Matthay MA, Network NA (2014) Subphenotypes in acute respiratory distress syndrome: latent class analysis of data from two randomised controlled trials. Lancet Respir Med 2:611-620

19. Reilly JP, Bellamy S, Shashaty MG, Gallop R, Meyer NJ, Lanken PN, Kaplan S, Holena DN, May AK, Ware LB, Christie JD (2014) Heterogeneous phenotypes of acute respiratory distress syndrome after major trauma. Ann Am Thorac Soc 11:728-736

20. Luo L, Shaver CM, Zhao Z, Koyama T, Calfee CS, Bastarache JA, Ware LB (2017) Clinical predictors of hospital mortality differ between direct and indirect ARDS. Chest 151:755-763

21. Calfee CS, Janz DR, Bernard GR, May AK, Kangelaris KN, Matthay MA, Ware LB (2015) Distinct molecular phenotypes of direct vs indirect ARDS in single-center and multicenter studies. Chest 147:1539-1548

22. Erickson SE, Martin GS, Davis JL, Matthay MA, Eisner MD, NIH NHLBI ARDS Network (2009) Recent trends in acute lung injury mortality: 1996-2005. Crit Care Med 37:1574-1579

23. Zhang Z, Spieth PM, Chiumello D, Goyal H, Torres A, Laffey JG, Hong Y (2019) Declining mortality in patients with acute respiratory distress syndrome: an analysis of the acute respiratory distress syndrome network trials. Crit Care Med 47:315-323

24. Eisner MD, Thompson T, Hudson LD, Luce JM, Hayden D, Schoenfeld D, Matthay MA, Acute Respiratory Distress Syndrome Network (2001) Efficacy of low tidal volume ventilation in patients with different clinical risk factors for acute lung injury and the acute respiratory distress syndrome. Am J Respir Crit Care Med 164:231-236

25. Eworuke E, Major JM, Gilbert McClain LI (2018) National incidence rates for acute respiratory distress syndrome (ARDS) and ARDS cause-specific factors in the United States (2006-2014). J Crit Care 47:192-197

26. Birkner DR, Halvachizadeh S, Pape HC, Pfeifer R (2020) Mortality of adult respiratory distress syndrome in trauma patients: a systematic review over a period of four decades. World J Surg 44:2243-2254

27. Eberhard LW, Morabito DJ, Matthay MA, Mackersie RC, Campbell AR, Marks JD, Alonso JA, Pittet JF (2000) Initial severity of metabolic acidosis predicts the development of acute lung injury in severely traumatized patients. Crit Care Med 28:125-131

28. Vossoughi S, Gorlin J, Kessler DA, Hillyer CD, Van Buren NL, Jimenez A, Shaz BH (2019) Ten years of TRALI mitigation: measuring our progress. Transfusion 59:2567-2574

29. Toy P, Gajic O, Bacchetti P, Looney MR, Gropper MA, Hubmayr R, Lowell CA, Norris PJ, Murphy EL, Weiskopf RB, Wilson G, Koenigsberg M, Lee D, Schuller R, Wu P, Grimes B, Gandhi MJ, Winters JL, Mair D, Hirschler N, Sanchez Rosen R, Matthay MA, TRALI Study Group (2012) Transfusion-related acute lung injury: incidence and risk factors. Blood 119:1757-1767

30. Sheu CC, Gong MN, Zhai R, Bajwa EK, Chen F, Thompson BT, Christiani DC (2010) The influence of infection sites on development and mortality of ARDS. Intensive Care Med 36:963-970

31. Auriemma CL, Zhuo H, Delucchi K, Deiss T, Liu T, Jauregui A, Ke S, Vessel K, Lippi M, Seeley E, Kangelaris KN, Gomez A, Hendrickson C, Liu KD, Matthay MA, Ware LB, Calfee CS (2020) Acute respiratory distress syndrome-attributable mortality in critically ill patients with sepsis. Intensive Care Med 46:1222-1231

32. The RECOVERY Collaborative Group (2020) Dexamethasone in hospitalized patients with Covid-19_preliminary report. N Engl J Med. https:// doi.org/10.1056/NEJMoa2021436

33. Lewis SR, Pritchard MW, Thomas CM, Smith AF (2019) Pharmacological agents for adults with acute respiratory distress syndrome. Cochrane Database Syst Rev 7:CD004477 
34. Villar J, Ferrando C, Martinez D, Ambros A, Munoz T, Soler JA, Aguilar G, Alba F, Gonzalez-Higueras E, Conesa LA, Martin-Rodriguez C, DiazDominguez FJ, Serna-Grande P, Rivas R, Ferreres J, Belda J, Capilla L, Tallet A, Anon JM, Fernandez RL, Gonzalez-Martin JM (2020) Dexamethasone treatment for the acute respiratory distress syndrome: a multicentre, randomised controlled trial. Lancet Respir Med 8:267-276

35. Matthay MA, Wick KD (2020) Corticosteroids, COVID-19 pneumonia and acute respiratory distress syndrome. J Clin Investig. https://doi. org/10.1172/JCl143331

36. ARDS Definition Task Force, Ranieri VM, Rubenfeld GD, Thompson BT, Ferguson ND, Caldwell E, Fan E, Camporota L, Slutsky AS (2012) Acute respiratory distress syndrome: the Berlin definition. JAMA 307:2526-2533

37. Ferguson ND, Fan E, Camporota L, Antonelli M, Anzueto A, Beale R, Brochard L, Brower R, Esteban A, Gattinoni L, Rhodes A, Slutsky AS, Vincent JL, Rubenfeld GD, Thompson BT, Ranieri VM (2012) The Berlin definition of ARDS: an expanded rationale, justification, and supplementary material. Intensive Care Med 38:1573-1582

38. Papazian L, Forel JM, Gacouin A, Penot-Ragon C, Perrin G, Loundou A, Jaber S, Arnal JM, Perez D, Seghboyan JM, Constantin JM, Courant P, Lefrant JY, Guerin C, Prat G, Morange S, Roch A, ACURASYS Study Investigators (2010) Neuromuscular blockers in early acute respiratory distress syndrome. N Engl J Med 363:1107-1116

39. The National Heart, Lung and Blood Institute PETAL Clinical Trials Network (2019) Early neuromuscular blockade in the acute respiratory distress syndrome. N Engl J Med 380:1997-2008

40. Beitler JR, Sarge T, Banner-Goodspeed VM, Gong MN, Cook D, Novack V, Loring SH, Talmor D, EPVent-2 Study Group (2019) Effect of titrating positive end-expiratory pressure (PEEP) with an esophageal pressureguided strategy vs an empirical high PEEP-Fio2 strategy on death and days free from mechanical ventilation among patients with acute respiratory distress syndrome: a randomized clinical trial. JAMA 321:846-857

41. Villar J, Perez-Mendez L, Blanco J, Anon JM, Blanch L, Belda J, SantosBouza A, Fernandez RL, Kacmarek RM, Spanish Initiative for Epidemiology, Stratification, and Therapies for ARDS (SIESTA) Network (2013) A universal definition of ARDS: the $\mathrm{PaO}_{2} / \mathrm{FiO}_{2}$ ratio under a standard ventilatory setting - a prospective, multicenter validation study. Intensive Care Med 39:583-592

42. Villar J, Perez-Mendez L, Lopez J, Belda J, Blanco J, Saralegui I, SuarezSipmann F, Lopez J, Lubillo S, Kacmarek RM, HELP Network (2007) An early PEEP/FIO 2 trial identifies different degrees of lung injury in patients with acute respiratory distress syndrome. Am J Respir Crit Care Med 176:795-804

43. Nuckton TJ, Alonso JA, Kallet RH, Daniel BM, Pittet JF, Eisner MD, Matthay MA (2002) Pulmonary dead-space fraction as a risk factor for death in the acute respiratory distress syndrome. N Engl J Med 346:1281-1286

44. Kallet RH, Alonso JA, Pittet JF, Matthay MA (2004) Prognostic value of the pulmonary dead-space fraction during the first 6 days of acute respiratory distress syndrome. Respir Care 49:1008-1014

45. Beitler JR, Thompson BT, Matthay MA, Talmor D, Liu KD, Zhuo H, Hayden D, Spragg RG, Malhotra A (2015) Estimating dead-space fraction for secondary analyses of acute respiratory distress syndrome clinical trials. Crit Care Med 43:1026-1035

46. Sinha P, Calfee CS, Beitler JR, Soni N, Ho K, Matthay MA, Kallet RH (2019) Physiologic analysis and clinical performance of the ventilatory ratio in acute respiratory distress syndrome. Am J Respir Crit Care Med 199:333-341

47. Goligher EC, Kavanagh BP, Rubenfeld GD, Ferguson ND (2015) Physiologic responsiveness should guide entry into randomized controlled trials. Am J Respir Crit Care Med 192:1416-1419

48. Goligher EC, Amato MBP, Slutsky AS (2017) Applying precision medicine to trial design using physiology. extracorporeal $\mathrm{CO}_{2}$ removal for acute respiratory distress syndrome. Am J Respir Crit Care Med 196:558-568

49. Beitler JR (2019) Bedside respiratory physiology to detect risk of lung injury in acute respiratory distress syndrome. Curr Opin Crit Care 25:3-11

50. Gattinoni L, Tonetti T, Cressoni M, Cadringher P, Herrmann P, Moerer O, Protti A, Gotti M, Chiurazzi C, Carlesso E, Chiumello D, Quintel M (2016) Ventilator-related causes of lung injury: the mechanical power. Intensive Care Med 42:1567-1575
51. Amato MB, Meade MO, Slutsky AS, Brochard L, Costa EL, Schoenfeld DA, Stewart TE, Briel M, Talmor D, Mercat A, Richard JC, Carvalho CR, Brower RG (2015) Driving pressure and survival in the acute respiratory distress syndrome. N Engl J Med 372:747-755

52. Beitler JR, Majumdar R, Hubmayr RD, Malhotra A, Thompson BT, Owens RL, Loring SH, Talmor D (2016) Volume delivered during recruitment maneuver predicts lung stress in acute respiratory distress syndrome. Crit Care Med 44:91-99

53. Talmor D, Sarge T, O'Donnell CR, Ritz R, Malhotra A, Lisbon A, Loring SH (2006) Esophageal and transpulmonary pressures in acute respiratory failure. Crit Care Med 34:1389-1394

54. Chiumello D, Carlesso E, Cadringher P, Caironi P, Valenza F, Polli F, Tallarini F, Cozzi P, Cressoni M, Colombo A, Marini JJ, Gattinoni L (2008) Lung stress and strain during mechanical ventilation for acute respiratory distress syndrome. Am J Respir Crit Care Med 178:346-355

55. Fumagalli J, Berra L, Zhang C, Pirrone M, Santiago RRS, Gomes S, Magni F, Dos Santos GAB, Bennett D, Torsani V, Fisher D, Morais C, Amato MBP, Kacmarek RM (2017) Transpulmonary pressure describes lung morphology during decremental positive end-expiratory pressure trials in obesity. Crit Care Med 45:1374-1381

56. Amato MB, Barbas CS, Medeiros DM, Magaldi RB, Schettino GP, LorenziFilho G, Kairalla RA, Deheinzelin D, Munoz C, Oliveira R, Takagaki TY, Carvalho CR (1998) Effect of a protective-ventilation strategy on mortality in the acute respiratory distress syndrome. N Engl J Med 338:347-354

57. Brower RG, Matthay MA, Morris A, Schoenfeld D, Thompson BT, Wheeler A, The Acute Respiratory Distress Syndrome Network (2000) Ventilation with lower tidal volumes as compared with traditional tidal volumes for acute lung injury and the acute respiratory distress syndrome. N Engl J Med 342:1301-1308

58. Goligher EC, Kavanagh BP, Rubenfeld GD, Adhikari NK, Pinto R, Fan E, Brochard L, Granton JT, Mercat A, Marie Richard JC, Chretien JM, Jones GL, Cook DJ, Stewart TE, Slutsky AS, Meade MO, Ferguson ND (2014) Oxygenation response to positive end-expiratory pressure predicts mortality in acute respiratory distress syndrome. A secondary analysis of the LOVS and ExPress trials. Am J Respir Crit Care Med 190:70-76

59. Santschi M, Jouvet P, Leclerc F, Gauvin F, Newth CJ, Carroll CL, Flori H, Tasker RC, Rimensberger PC, Randolph AG, PALIVE Investigators; Pediatric Acute Lung Injury and Sepsis Investigators Network (PALISI); European Society of Pediatric and Neonatal Intensive Care (ESPNIC) (2010) Acute lung injury in children: therapeutic practice and feasibility of international clinical trials. Pediatr Crit Care Med 11:681-689

60. Santschi M, Randolph AG, Rimensberger PC, Jouvet P, Pediatric Acute Lung Injury Mechanical Ventilation Investigators; Pediatric Acute Lung Injury and Sepsis Investigators Network; European Society of Pediatric and Neonatal Intensive Care (2013) Mechanical ventilation strategies in children with acute lung injury: a survey on stated practice pattern. Pediatr Crit Care Med 14:e332-337

61. Sapru A, Flori H, Quasney MW, Dahmer MK, Pediatric Acute Lung Injury Consensus Conference Group (2015) Pathobiology of acute respiratory distress syndrome. Pediatr Crit Care Med 16:56-22

62. Yehya N, Harhay MO, Klein MJ, Shein SL, Pineres-Olave BE, Izquierdo L, Sapru A, Emeriaud G, Spinella PC, Flori HR, Dahmer MK, Maddux AB, Lopez-Fernandez YM, Haileselassie B, Hsing DD, Chima RS, Hassinger AB, Valentine SL, Rowan CM, Kneyber MCJ, Smith LS, Khemani RG, Thomas NJ, Pediatric Acute Respiratory Distress Syndrome Incidence and Epidemiology (PARDIE) V1 Investigators and the Pediatric Acute Lung Injury and Sepsis Investigators (PALISI) Network (2020) Predicting mortality in children with pediatric acute respiratory distress syndrome: a pediatric acute respiratory distress syndrome incidence and epidemiology study. Crit Care Med 48:e514-e522

63. Thomas NJ, Shaffer ML, Willson DF, Shih MC, Curley MA (2010) Defining acute lung disease in children with the oxygenation saturation index. Pediatr Crit Care Med 11:12-17

64. Rimensberger PC, Cheifetz IM, Pediatric Acute Lung Injury Consensus Conference Group (2015) Ventilatory support in children with pediatric acute respiratory distress syndrome: proceedings from the pediatric acute lung injury consensus conference. Pediatr Crit Care Med 16:\$51-60

65. Khemani RG, Smith LS, Zimmerman JJ, Erickson S, Pediatric Acute Lung Injury Consensus Conference Group (2015) Pediatric acute respiratory distress syndrome: definition, incidence, and epidemiology: 
proceedings from the pediatric acute lung injury consensus conference. Pediatr Crit Care Med 16:S23-40

66. Constantin JM, Grasso S, Chanques G, Aufort S, Futier E, Sebbane M, Jung B, Gallix B, Bazin JE, Rouby JJ, Jaber S (2010) Lung morphology predicts response to recruitment maneuver in patients with acute respiratory distress syndrome. Crit Care Med 38:1108-1117

67. Puybasset L, Gusman P, Muller JC, Cluzel P, Coriat P, Rouby JJ (2000) Regional distribution of gas and tissue in acute respiratory distress syndrome. III. Consequences for the effects of positive end-expiratory pressure. CT Scan ARDS Study Group. Adult Respiratory Distress Syndrome. Intensive Care Med 26:1215-1227

68. Constantin JM, Jabaudon M, Lefrant JY, Jaber S, Quenot JP, Langeron $\mathrm{O}$, Ferrandiere M, Grelon F, Seguin P, Ichai C, Veber B, Souweine B, Uberti T, Lasocki S, Legay F, Leone M, Eisenmann N, Dahyot-Fizelier C, Dupont H, Asehnoune K, Sossou A, Chanques G, Muller L, Bazin JE, Monsel A, Borao L, Garcier JM, Rouby JJ, Pereira B, Futier E, AZUREA Network (2019) Personalised mechanical ventilation tailored to lung morphology versus low positive end-expiratory pressure for patients with acute respiratory distress syndrome in France (the LIVE study): a multicentre, single-blind, randomised controlled trial. Lancet Respir Med 7:870-880

69. Warren MA, Zhao Z, Koyama T, Bastarache JA, Shaver CM, Semler MW, Rice TW, Matthay MA, Calfee CS, Ware LB (2018) Severity scoring of lung oedema on the chest radiograph is associated with clinical outcomes in ARDS. Thorax 73:840-846

70. National Heart, Lung, and Blood Institute Acute Respiratory Distress Syndrome Clinical Trials N, Wiedemann HP, Wheeler AP, Bernard GR, Thompson BT, Hayden D, deBoisblanc B, Connors AF Jr, Hite RD, Harabin AL (2006) Comparison of two fluid-management strategies in acute lung injury. N Engl J Med 354:2564-2575

71. Jabaudon M, Audard J, Pereira B, Jaber S, Lefrant JY, Blondonnet R, Godet T, Futier E, Lambert C, Bazin JE, Bastarache JA, Constantin JM, Ware LB, LIVE Study Group and the AZUREA Network (2020) Early changes over time in the radiographic assessment of lung edema (RALE) score are associated with survival in acute respiratory distress syndrome. Chest

72. Kotok D, Yang L, Evankovich JW, Bain W, Dunlap DG, Shah F, Zhang Y, Manatakis DV, Benos PV, Barbash IJ, Rapport SF, Lee JS, Morris A, McVerry BJ, Kitsios GD (2020) The evolution of radiographic edema in ARDS and its association with clinical outcomes: a prospective cohort study in adult patients. J Crit Care 56:222-228

73. de Blic J, Midulla F, Barbato A, Clement A, Dab I, Eber E, Green C, Grigg J, Kotecha S, Kurland G, Pohunek P, Ratjen F, Rossi G (2000) Bronchoalveolar lavage in children. ERS Task Force on bronchoalveolar lavage in children. Eur Respir J 15:217-231

74. Schnabel RM, van der Velden K, Osinski A, Rohde G, Roekaerts PM, Bergmans DC (2015) Clinical course and complications following diagnostic bronchoalveolar lavage in critically ill mechanically ventilated patients. BMC Pulm Med 15:107

75. Lindgren S, Odenstedt H, Erlandsson K, Grivans C, Lundin S, Stenqvist O (2008) Bronchoscopic suctioning may cause lung collapse: a lung model and clinical evaluation. Acta Anaesthesiol Scand 52:209-218

76. Perkins GD, Chatterjie S, McAuley DF, Gao F, Thickett DR (2006) Role of nonbronchoscopic lavage for investigating alveolar inflammation and permeability in acute respiratory distress syndrome. Crit Care Med 34:57-64

77. McNeil JB, Shaver CM, Kerchberger VE, Russell DW, Grove BS, Warren MA, Wickersham NE, Ware LB, McDonald WH, Bastarache JA (2018) Novel method for noninvasive sampling of the distal airspace in acute respiratory distress syndrome. Am J Respir Crit Care Med 197:1027-1035

78. Chesnutt AN, Matthay MA, Tibayan FA, Clark JG (1997) Early detection of type III procollagen peptide in acute lung injury. Pathogenetic and prognostic significance. Am J Respir Crit Care Med 156:840-845

79. Marshall RP, Bellingan G, Webb S, Puddicombe A, Goldsack N, McAnulty RJ, Laurent GJ (2000) Fibroproliferation occurs early in the acute respiratory distress syndrome and impacts on outcome. Am J Respir Crit Care Med 162:1783-1788

80. Forel JM, Guervilly C, Hraiech S, Voillet F, Thomas G, Somma C, Secq V, Farnarier C, Payan MJ, Donati SY, Perrin G, Trousse D, Dizier S, Chiche L, Baumstarck K, Roch A, Papazian L (2015) Type III procollagen is a reliable marker of ARDS-associated lung fibroproliferation. Intensive Care Med 41:1-11

81. Hamon A, Scemama U, Bourenne J, Daviet F, Coiffard B, Persico N, Adda M, Guervilly C, Hraiech S, Chaumoitre K, Roch A, Papazian L, Forel JM (2019) Chest CT scan and alveolar procollagen III to predict lung fibroproliferation in acute respiratory distress syndrome. Ann Intensive Care 9:42

82. Bos LDJ, Sinha P, Dickson RP (2020) The perils of premature phenotyping in COVID-19: a call for caution. Eur Respir J 56

83. Sinha P, Calfee CS (2019) Phenotypes in acute respiratory distress syndrome: moving towards precision medicine. Curr Opin Crit Care 25:12-20

84. Famous KR, Delucchi K, Ware LB, Kangelaris KN, Liu KD, Thompson BT, Calfee CS, ARDS Network (2017) Acute respiratory distress syndrome subphenotypes respond differently to randomized fluid management strategy. Am J Respir Crit Care Med 195:331-338

85. Calfee CS, Delucchi KL, Sinha P, Matthay MA, Hackett J, Shankar-Hari M, McDowell C, Laffey JG, O'Kane CM, McAuley DF, Irish Critical Care Trials Group (2018) Acute respiratory distress syndrome subphenotypes and differential response to simvastatin: secondary analysis of a randomised controlled trial. Lancet Respir Med 6:691-698

86. Sinha P, Delucchi KL, McAuley DF, O'Kane CM, Matthay MA, Calfee CS (2020) Development and validation of parsimonious algorithms to classify acute respiratory distress syndrome phenotypes: a secondary analysis of randomised controlled trials. Lancet Respir Med 8:247-257

87. The National Heart, Lung, and Blood Institute ARDS Clinical Trials Network (2004) Higher versus lower positive end-expiratory pressures in patients with the acute respiratory distress syndrome. N Engl J Med 351:327-336

88. McAuley DF, Laffey JG, O'Kane CM, Perkins GD, Mullan B, Trinder TJ, Johnston P, Hopkins PA, Johnston AJ, McDowell C, McNally C, the HARP-2 Investigators for the Irish Critical Care Trials Group (2014) Simvastatin in the acute respiratory distress syndrome. N Engl J Med 371:1695-1703

89. Bos $L D$, Schouten $L R$, van Vught $L A$, Wiewel MA, Ong DSY, Cremer $O$, Artigas A, Martin-Loeches I, Hoogendijk AJ, van der Poll T, Horn J, Juffermans N, Calfee CS, Schultz MJ, MARS consortium (2017) Identification and validation of distinct biological phenotypes in patients with acute respiratory distress syndrome by cluster analysis. Thorax 72:876-883

90. Sinha P, Calfee CS, Cherian S, Brealey D, Cutler S, King C, Killick C, Richards O, Cheema Y, Bailey C, Reddy K, Delucchi KL, Shankar-Hari M, Gordon AC, Shyamsundar M, O'Kane CM, McAuley DF, Szakmany T (2020) Prevalence of phenotypes of acute respiratory distress syndrome in critically ill patients with COVID-19: a prospective observational study. Lancet Respir Med. https://doi.org/10.1016/S2213-2600(20)30366-0

91. Scicluna BP, van Vught LA, Zwinderman AH, Wiewel MA, Davenport EE, Burnham KL, Nurnberg P, Schultz MJ, Horn J, Cremer OL, Bonten MJ, Hinds CJ, Wong HR, Knight JC, van der Poll T, MARS consortium (2017) Classification of patients with sepsis according to blood genomic endotype: a prospective cohort study. Lancet Respir Med 5:816-826

92. Antcliffe DB, Burnham KL, Al-Beidh F, Santhakumaran S, Brett SJ, Hinds CJ, Ashby D, Knight JC, Gordon AC (2019) Transcriptomic signatures in sepsis and a differential response to steroids. From the VANISH randomized trial. Am J Respir Crit Care Med 199:980-986

93. Davenport EE, Burnham KL, Radhakrishnan J, Humburg P, Hutton P, Mills TC, Rautanen A, Gordon AC, Garrard C, Hill AV, Hinds CJ, Knight JC (2016) Genomic landscape of the individual host response and outcomes in sepsis: a prospective cohort study. Lancet Respir Med 4:259-271

94. Sweeney TE, Azad TD, Donato M, Haynes WA, Perumal TM, Henao R, Bermejo-Martin JF, Almansa R, Tamayo E, Howrylak JA, Choi A, Parnell GP, Tang B, Nichols M, Woods CW, Ginsburg GS, Kingsmore SF, Omberg L, Mangravite LM, Wong HR, Tsalik EL, Langley RJ, Khatri P (2018) Unsupervised analysis of transcriptomics in bacterial sepsis across multiple datasets reveals three robust clusters. Crit Care Med 46:915-925

95. Bos LDJ, Scicluna BP, Ong DSY, Cremer O, van der Poll T, Schultz MJ (2019) Understanding heterogeneity in biologic phenotypes of acute respiratory distress syndrome by leukocyte expression profiles. Am J Respir Crit Care Med 200:42-50

96. Morrell ED, Radella F 2nd, Manicone AM, Mikacenic C, Stapleton RD, Gharib SA, Wurfel MM (2018) Peripheral and alveolar cell transcriptional 
programs are distinct in acute respiratory distress syndrome. Am J Respir Crit Care Med 197:528-532

97. Kao KC, Chiu LC, Hung CY, Chang CH, Yang CT, Huang CC, Hu HC (2017) Coinfection and mortality in pneumonia-related acute respiratory distress syndrome patients with bronchoalveolar lavage: a prospective observational study. Shock 47:615-620

98. Metlay JP, Waterer GW, Long AC, Anzueto A, Brozek J, Crothers K, Cooley LA, Dean NC, Fine MJ, Flanders SA, Griffin MR, Metersky ML, Musher DM, Restrepo MI, Whitney CG (2019) Diagnosis and treatment of adults with community-acquired pneumonia. An official clinical practice guideline of the American Thoracic Society and Infectious Diseases Society of America. Am J Respir Crit Care Med 200:e45-e67

99. Kalil AC, Metersky ML, Klompas M, Muscedere J, Sweeney DA, Palmer LB, Napolitano LM, O'Grady NP, Bartlett JG, Carratala J, El Solh AA, Ewig S, Fey PD, File TM Jr, Restrepo MI, Roberts JA, Waterer GW, Cruse P, Knight SL, Brozek JL (2016) Management of adults with hospitalacquired and ventilator-associated pneumonia: 2016 clinical practice guidelines by the Infectious Diseases Society of America and the American Thoracic Society. Clin Infect Dis 63:e61-e111

100. Gadsby NJ, Russell CD, McHugh MP, Mark H, Conway Morris A, Laurenson IF, Hill AT, Templeton KE (2016) Comprehensive molecular testing for respiratory pathogens in community-acquired pneumonia. Clin Infect Dis 62:817-823

101. Arabi YM, Fowler R, Hayden FG (2020) Critical care management of adults with community-acquired severe respiratory viral infection. Intensive Care Med 46:315-328

102. Karhu J, Ala-Kokko TI, Vuorinen T, Ohtonen P, Syrjala H (2014) Lower respiratory tract virus findings in mechanically ventilated patients with severe community-acquired pneumonia. Clin Infect Dis 59:62-70

103. Hasvold J, Sjoding M, Pohl K, Cooke C, Hyzy RC (2016) The role of human metapneumovirus in the critically ill adult patient. J Crit Care 31:233-237

104. Fischer $\mathrm{N}$, Rohde H, Indenbirken D, Gunther T, Reumann K, Lutgehetmann M, Meyer T, Kluge S, Aepfelbacher M, Alawi M, Grundhoff A (2014) Rapid metagenomic diagnostics for suspected outbreak of severe pneumonia. Emerg Infect Dis 20:1072-1075

105. Leo S, Gaïa N, Ruppé E, Emonet S, Girard M, Lazarevic V, Schrenzel J (2017) Detection of Bacterial Pathogens from Broncho-Alveolar Lavage by Next-Generation Sequencing. Int J Mol Sci. 18(9):2011. https://doi. org/10.3390/ijms18092011

106. Madi N, Al-Nakib W, Mustafa AS, Habibi N (2018) Metagenomic analysis of viral diversity in respiratory samples from patients with respiratory tract infections in Kuwait. J Med Virol 90:412-420

107. Lysholm F, Wetterbom A, Lindau C, Darban H, Bjerkner A, Fahlander K, Lindberg AM, Persson B, Allander T, Andersson B (2012) Characterization of the viral microbiome in patients with severe lower respiratory tract infections, using metagenomic sequencing. PLoS ONE 7:e30875

108. Langelier C, Kalantar KL, Moazed F, Wilson MR, Crawford ED, Deiss T, Belzer A, Bolourchi S, Caldera S, Fung M, Jauregui A, Malcolm K, Lyden A, Khan L, Vessel K, Quan J, Zinter M, Chiu CY, Chow ED, Wilson J, Mille S, Matthay MA, Pollard KS, Christenson S, Calfee CS, DeRisi JL (2018) Integrating host response and unbiased microbe detection for lower respiratory tract infection diagnosis in critically ill adults. Proc Natl Acad Sci USA 115:E12353-E12362

109. Hong DK, Blauwkamp TA, Kertesz M, Bercovici S, Truong C, Banaei N (2018) Liquid biopsy for infectious diseases: sequencing of cell-free plasma to detect pathogen DNA in patients with invasive fungal disease. Diagn Microbiol Infect Dis 92:210-213

110. Langelier C, Fung M, Caldera S, Deiss T, Lyden A, Prince BC, Serpa PH, Moazed F, Chin-Hong P, DeRisi JL, Calfee CS (2020) Detection of pneumonia pathogens from plasma cell-free DNA. Am J Respir Crit Care Med 201:491-495

111. Zhu N, Zhang D, Wang W, Li X, Yang B, Song J, Zhao X, Huang B, Shi W, Lu R, Niu P, Zhan F, Ma X, Wang D, Xu W, Wu G, Gao GF, Tan W (2020) A Novel Coronavirus from Patients with Pneumonia in China, 2019. New England Journal of Medicine 382:727-733

112. Zhou $P$, Yang $X L$, Wang $X G$, Hu B, Zhang $L$, Zhang W, Si HR, Zhu Y, Li $B$, Huang CL, Chen HD, Chen J, Luo Y, Guo H, Jiang RD, Liu MQ, Chen Y, Shen XR, Wang X, Zheng XS, Zhao K, Chen QJ, Deng F, Liu LL, Yan B, Zhan FX, Wang YY, Xiao GF, Shi ZL (2020) A pneumonia outbreak associated with a new coronavirus of probable bat origin. Nature 579:270-273

113. Lu R, Zhao X, Li J, Niu P, Yang B, Wu H, Wang W, Song H, Huang B, Zhu N, Bi Y, Ma X, Zhan F, Wang L, Hu T, Zhou H, Hu Z, Zhou W, Zhao L, Chen J, Meng Y, Wang J, Lin Y, Yuan J, Xie Z, Ma J, Liu WJ, Wang D, Xu W, Holmes EC, Gao GF, Wu G, Chen W, Shi W, Tan W (2020) Genomic characterisation and epidemiology of 2019 novel coronavirus: implications for virus origins and receptor binding. Lancet 395:565-574

114. Chan JF, Yuan S, Kok KH, To KK, Chu H, Yang J, Xing F, Liu J, Yip CC, Poon RW, Tsoi HW, Lo SK, Chan KH, Poon VK, Chan WM, Ip JD, Cai JP, Cheng VC, Chen H, Hui CK, Yuen KY (2020) A familial cluster of pneumonia associated with the 2019 novel coronavirus indicating person-toperson transmission: a study of a family cluster. Lancet 395:514-523

115. Li Q, Guan X, Wu P, Wang X, Zhou L, Tong Y, Ren R, Leung KSM, Lau EHY, Wong JY, Xing X, Xiang N, Wu Y, Li C, Chen Q, Li D, Liu T, Zhao J, Liu M, Tu W, Chen C, Jin L, Yang R, Wang Q, Zhou S, Wang R, Liu H, Luo Y, Liu Y, Shao G, Li H, Tao Z, Yang Y, Deng Z, Liu B, Ma Z, Zhang Y, Shi G, Lam TTY, Wu JT, Gao GF, Cowling BJ, Yang B, Leung GM, Feng Z (2020) Early Transmission Dynamics in Wuhan, China, of Novel Coronavirus-Infected Pneumonia. N Engl J Med 382:1199-1207

116. The National Heart, Lung, and Blood Institute Acute Respiratory Distress Syndrome (ARDS) Clinical Trials Network (2006) Efficacy and safety of corticosteroids for persistent acute respiratory distress syndrome. $\mathrm{N}$ Engl J Med 354:1671-1684

117. The National Heart, Lung, and Blood Institute Acute Respiratory Distress Syndrome (ARDS) Clinical Trials Network (2011) Randomized, placebocontrolled clinical trial of an aerosolized beta(2)-agonist for treatment of acute lung injury. Am J Respir Crit Care Med 184:561-568

118. Taylor RW, Zimmerman JL, Dellinger RP, Straube RC, Criner GJ, Davis K Jr, Kelly KM, Smith TC, Inhaled Nitric Oxide in ARDS Study Group (2004) Low-dose inhaled nitric oxide in patients with acute lung injury: a randomized controlled trial. JAMA 291:1603-1609

119. Spragg RG, Lewis JF, Walmrath HD, Johannigman J, Bellingan G, Laterre PF, Witte MC, Richards GA, Rippin G, Rathgeb F, Hafner D, Taut FJ, Seeger W (2004) Effect of recombinant surfactant protein C-based surfactant on the acute respiratory distress syndrome. N Engl J Med 351:884-892

120. Group WHOREAfC-TW, Sterne JAC, Murthy S, Diaz JV, Slutsky AS, Villar J, Angus DC, Annane D, Azevedo LCP, Berwanger O, Cavalcanti $A B$, Dequin PF, Du B, Emberson J, Fisher D, Giraudeau B, Gordon AC, Granholm A, Green C, Haynes R, Heming N, Higgins JPT, Horby P, Juni P, Landray MJ, Le Gouge A, Leclerc M, Lim WS, Machado FR, MCArthur C, Meziani F, Moller MH, Perner A, Petersen MW, Savovic J, Tomazini B, Veiga VC, Webb S, Marshall JC, (2020) Association Between Administration of Systemic Corticosteroids and Mortality Among Critically III Patients With COVID-19: A Meta-analysis. JAMA 324:1330-1341

121. Panka BA, de Grooth HJ, Spoelstra-de Man AM, Looney MR, Tuinman PR (2017) Prevention or treatment of ards with aspirin: a review of preclinical models and meta-analysis of clinical studies. Shock 47:13-21

122. Kor DJ, Carter RE, Park PK, Festic E, Banner-Goodspeed VM, Hinds R, Talmor D, Gajic O, Ware LB, Gong MN, US Critical IIIness and Injury Trials Group: Lung Injury Prevention with Aspirin Study Group (USCIITG: LIPSA) (2016) Effect of aspirin on development of ARDS in at-risk patients presenting to the emergency department: the LIPS-A randomized clinical trial. JAMA 315:2406-2414

123. The National Heart, Lung, and Blood Institute PETAL Clinical Trials Network (2019) Early high-dose vitamin D3 for critically ill, vitamin D-deficient patients. N Engl J Med 381:2529-2540

124. Levitt JE, Bedi H, Calfee CS, Gould MK, Matthay MA (2009) Identification of early acute lung injury at initial evaluation in an acute care setting prior to the onset of respiratory failure. Chest 135:936-943

125. Levitt JE, Calfee CS, Goldstein BA, Vojnik R, Matthay MA (2013) Early acute lung injury: criteria for identifying lung injury prior to the need for positive pressure ventilation. Crit Care Med 41:1929-1937

126. Frat JP, Thille AW, Mercat A, Girault C, Ragot S, Perbet S, Prat G, Boulain T, Morawiec E, Cottereau A, Devaquet J, Nseir S, Razazi K, Mira JP, Argaud L, Chakarian JC, Ricard JD, Wittebole X, Chevalier S, Herbland A, Fartoukh M, Constantin JM, Tonnelier JM, Pierrot M, Mathonnet A, Beduneau G, Deletage-Metreau C, Richard JC, Brochard L, Robert R, the FLORALI Study Group and the REVA Network (2015) High-flow oxygen through nasal cannula in acute hypoxemic respiratory failure. N Engl J Med 372:2185-2196 
127. Festic E, Carr GE, Cartin-Ceba R, Hinds RF, Banner-Goodspeed V, Bansal V, Asuni AT, Talmor D, Rajagopalan G, Frank RD, Gajic O, Matthay MA, Levitt JE (2017) Randomized clinical trial of a combination of an inhaled corticosteroid and beta agonist in patients at risk of developing the acute respiratory distress syndrome. Crit Care Med 45:798-805

128. Fowler AA 3rd, Fisher BJ, Kashiouris MG (2020) Vitamin C for sepsis and acute respiratory failure-reply. JAMA 323:792-793

129. Gainnier M, Roch A, Forel JM, Thirion X, Arnal JM, Donati S, Papazian L (2004) Effect of neuromuscular blocking agents on gas exchange in patients presenting with acute respiratory distress syndrome. Crit Care Med 32:113-119

130. Meyer NJ, Reilly JP, Anderson BJ, Palakshappa JA, Jones TK, Dunn TG, Shashaty MGS, Feng R, Christie JD, Opal SM (2018) Mortality benefit of recombinant human interleukin-1 receptor antagonist for sepsis varies by initial interleukin-1 receptor antagonist plasma concentration. Crit Care Med 46:21-28

131. Sinha P, Matthay MA, Calfee CS (2020) Is a "Cytokine Storm" Relevant to COVID-19? JAMA Intern Med 180:1152-1154
132. Liu KD, Levitt J, Zhuo H, Kallet RH, Brady S, Steingrub J, Tidswell M, Siegel MD, Soto G, Peterson MW, Chesnutt MS, Phillips C, Weinacker A, Thompson BT, Eisner MD, Matthay MA (2008) Randomized clinical trial of activated protein $C$ for the treatment of acute lung injury. Am J Respir Crit Care Med 178:618-623

133. Barnes BJ, Adrover JM, Baxter-Stoltzfus A, Borczuk A, Cools-Lartigue J, Crawford JM, Dassler-Plenker J, Guerci P, Huynh C, Knight JS, Loda M, Looney MR, McAllister F, Rayes R, Renaud S, Rousseau S, Salvatore S, Schwartz RE, Spicer JD, Yost CC, Weber A, Zuo Y, Egeblad M (2020) Targeting potential drivers of COVID-19: Neutrophil extracellular traps. J Exp Med 217

134. Ackermann M, Verleden SE, Kuehnel M, Haverich A, Welte T, Laenger F, Vanstapel A, Werlein C, Stark H, Tzankov A, Li WW, Li VW, Mentzer SJ, Jonigk D (2020) Pulmonary vascular endothelialitis, thrombosis, and angiogenesis in Covid-19. N Engl J Med 383:120-128 